\title{
Unobserved Performance of Hedge Funds
}

\author{
Vikas Agarwal, Stefan Ruenzi, and Florian Weigert ${ }^{*}$
}

This Version: September 2019

\begin{abstract}
We investigate hedge funds' unobserved performance $(U P)$, measured as the riskadjusted return difference between a fund firm's reported return and the hypothetical portfolio return derived from its long equity holdings disclosed on a quarterly basis. We find that high $U P$ is (i) positively associated with measures of managerial incentives, discretion, and skill, and (ii) driven by a fund firm's intraquarter trading in equity positions, derivatives usage, short selling, and confidential holdings. Fund firms with high $U P$ outperform fund firms with low $U P$ by more than $6 \%$ p.a. after accounting for typical hedge fund risk factors and fund characteristics.
\end{abstract}

Keywords: Confidential Holdings, Derivative Usage, Discretion, Frequent Trading, Hedge Funds, Managerial Incentives, Short Selling, Unobserved Performance

JEL Classification Numbers: G11, G23

\footnotetext{
*Vikas Agarwal is from Georgia State University, J. Mack Robinson College of Business, 35 Broad Street, Suite 1234, Atlanta GA 30303, USA. Email: vagarwal@ gsu.edu.Tel: +1-404-413-7326. Fax: +1-404-413-7312. Stefan Ruenzi is from the University of Mannheim, L9, 1-2, 68161 Mannheim, Germany. Email: ruenzi@bwl.uni-mannheim.de. Tel: +49-621-181-1646. Florian Weigert is from the University of St. Gallen, Swiss Institute of Banking and Finance, Unterer Graben 21, 9000 St. Gallen, Switzerland. Email: florian.weigert@unisg.ch. Tel: +41-71-224-7014. We thank Manuel Ammann, Steven Baker, Nick Baltas, Guillermo Baquero, Utpal Bhattacharya, Chris P. Clifford, Serge Darolles, Ralf Elsas, Günter Franke, Mike Gallmeyer, Mila Getmansky, Markus Glaser, Vincent Glode, Jens Jackwerth, Mark Hutchinson, Lars Kaiser, Christoph Kaserer, Olga Kolokolova, Philipp Krueger, Christoph Merkle, Lubos Pástor, Adam Reed, Markus Schmid, Daniel Schmidt, Claus Schmitt, Clemens Sialm, Sebastian Stoeckl, Christian Tiu, and seminar participants at the 2018 Hedge Fund \& Private Equity Conference in Paris, the 2018 Consortium on Trading Strategies and Institutional Investors in Cambridge, the 2018 Colloquium on Financial Markets in Cologne, the 2018 Swiss Finance Conference in Zurich, the 2018 Professional Asset Management Conference in Rotterdam, the 2018 FIRS Conference, HongKong Polytechnic University, Indian School of Business (ISB), LMU Munich, TU Munich, KLU Hamburg, the University of Constance, the University of Liechtenstein, the University of Luxembourg, and the University of St.Gallen for their helpful comments. Vikas Agarwal would like to thank the Centre for Financial Research (CFR) in Cologne for their continued support. All errors are our own.
} 


\title{
Unobserved Performance of Hedge Funds
}

\author{
This Version: September 2019
}

\begin{abstract}
We investigate hedge funds' unobserved performance $(U P)$, measured as the riskadjusted return difference between a fund firm's reported return and the hypothetical portfolio return derived from its long equity holdings disclosed on a quarterly basis. We find that high $U P$ is (i) positively associated with measures of managerial incentives, discretion, and skill, and (ii) driven by a fund firm's intraquarter trading in equity positions, derivatives usage, short selling, and confidential holdings. Fund firms with high $U P$ outperform fund firms with low $U P$ by more than $6 \%$ p.a. after accounting for typical hedge fund risk factors and fund characteristics.
\end{abstract}

Keywords: Confidential Holdings, Derivative Usage, Discretion, Frequent Trading, Hedge Funds, Managerial Incentives, Short Selling, Unobserved Performance

JEL Classification Numbers: G11, G23 


\section{Introduction}

Despite the growing importance of hedge funds in financial markets, there is still limited understanding about identifying skilled managers and the sources of their skill that can help to reliably predict their future performance. Hedge funds' lax regulation, opaque structure, and limited disclosure makes this task challenging, if not impossible.

Two strands of academic literature have made some progress through the use of two distinctive approaches. The first strand pursues a returns-based methodology to investigate the relation between funds' reported returns to a plethora of different risk factors. ${ }^{1}$ One of the main findings from this literature is that fund performance can be explained by different risk factors, but that the average fund manager seems to be skilled enough to deliver a positive and statistically significant net-of-fee alpha. The second strand of literature takes a different route and investigates the performance of portfolio holdings of funds. Due to limited disclosure requirements, most papers focus on analyzing funds' long equity positions disclosed to the Securities and Exchange Commission (SEC) on a quarterly basis. ${ }^{2}$ In contrast to the returns-based approach, empirical evidence for skill in hedge funds using the holdingsbased methodology has been relatively scarce. For example, Griffin and Xu (2009) document that hedge funds are no more skilled than mutual funds in terms of security selection and neither equal-weighted nor value-weighted returns of disclosed equity portfolios of funds significantly outperform the market return after fees. Several limitations of the holdingsbased approach can perhaps explain this lack of skill. These include having access to only quarterly snapshots, coverage of only large long equity positions (more than 10,000 shares or

\footnotetext{
${ }^{1}$ An incomplete list of papers that document the different risks explaining hedge fund performance include nonlinear risk (Agarwal and Naik, 2004; Fung and Hsieh, 2004), correlation risk (Buraschi, Kosowski, and Trojani, 2014), liquidity risk (Aragon, 2007; Sadka, 2010; Teo, 2011), macroeconomic uncertainty (Bali, Brown, and Caglayan, 2014), volatility risk (Bondarenko, 2004; Agarwal, Bakshi, and Huij, 2009; Agarwal, Arisoy, and Naik, 2017), rare disaster concerns (Gao, Gao, and Song, 2018), and tail risk (Agarwal, Ruenzi, and Weigert, 2017). For more details, see a recent survey by Agarwal, Mullally, and Naik (2015).

${ }^{2}$ There are few notable exceptions that investigate disclosed derivative positions of hedge funds (Aragon and Martin, 2012; Aragon, Martin, and Shi, 2018; Joenväärä, Kauppila, and Tolonen, 2018).
} 
$\$ 200,000)$, and potential distortion and intraquarter trading by managers to prevent others from inferring their trading strategies and positions.

Our paper addresses these prima facie conflicting findings on the existence of managerial skill in the hedge fund industry and drivers of such skill. For this purpose, we propose combining the returns- and holdings-based approaches. The underlying intuition behind our approach is as follows. When positive hedge fund alpha is existent (as documented in the returns-based studies), but not observed in the disclosed long equity positions, it must stem from the unobserved actions of hedge funds, i.e., actions which are not disclosed in the fund firms' quarterly long equity holdings. To capture this unobserved return component, we combine data on the hedge fund returns reported to commercial databases with data on the long-equity positions of hedge fund firms disclosed in their 13F filings. Specifically, we construct a new measure of skill, unobserved performance (or $U P$ ), which is the risk-adjusted difference between reported returns and hypothetical net buy-and-hold returns from long equity portfolio positions (after accounting for the estimated transaction costs associated with trading over the quarter) over the period from 1994 to $2012 .{ }^{3}$ We adjust for the known risk factors that influence hedge fund returns to control for exposure to nonequity asset classes in an attempt to isolate managerial skill. Consistent with the limited evidence of skill in disclosed long equity positions, we observe that the average risk-adjusted performance or alpha of $0.316 \%$ per month ( $t$-statistic of 3.31 ) for the hedge fund firms in our sample is almost entirely driven by the funds' $U P$ with an average alpha of $0.291 \%$ per month ( $t$-statistic of 3.76). In comparison, the fund firms' average alpha of their disclosed equity positions is $0.032 \%$ per month and statistically indistinguishable from zero.

These findings suggest that $U P$ might serve as a better measure of managerial skill than either the alpha estimated from reported returns or the alpha inferred from the disclosed

\footnotetext{
${ }^{3}$ Since reported returns are net of fees while hypothetical returns from buy-and-hold long equity portfolio are before fees, we repeat our analysis using gross-of-fee reported returns, and find similar results.
} 
long equity positions. Therefore, to better understand the sources of managerial skill, we next investigate which fund characteristics are associated with high $U P$. If $U P$ indeed captures skill, characteristics associated with it should predict better fund performance. We find strong evidence in favor of $U P$ reflecting managerial skill. Specifically, we find that smaller funds show high $U P$, consistent with the notion that these funds are more nimble and are less likely to suffer from capacity constraints compared to larger funds, and therefore perform better (Aggarwal and Jorion, 2010). In addition, UP is positively related to measures of managerial incentives (manager's pay-performance sensitivity or delta) and managerial discretion (proxied by a fund firm's lockup and redemption periods), both of which predict better future fund performance (Agarwal, Daniel, and Naik, 2009). Finally, we uncover a strong negative relation between $U P$ and a fund firm's $\mathrm{R}^{2}$ measure indicating that high $U P$ managers are more active and less exposed to standard or conventional risk factors, characteristics associated with better fund performance (Titman and Tiu, 2011).

Following these findings indicative of $U P$ being a skill measure, we further probe into the nature of hedge funds' trading strategies that can help them enhance $U P$. While the opaqueness of the industry makes it extremely challenging to provide definitive answers here, we nevertheless examine four potential trading channels in the paper. First, $U P$ could be related to active intraquarter trading of long-equity positions. Such frequent trading cannot be inferred from the disclosed positions of institutional investors and is shown to be potentially performance-enhancing (e.g., Puckett and Yan, 2011; Pástor, Stambaugh, and Taylor, 2017). Indeed, when investigating changes in a fund firm's disclosed long-equity portfolio from quarter $t$ to quarter $t+1$ as a proxy for intraquarter trading, we document that fund firms with high equity portfolio turnover exhibit high $U P$.

Second, UP is likely to be associated with a fund firm's derivative usage. Hedge funds are known to display nonlinear return profiles similar to mechanical out-of-the-money put 
option writing strategies to the equity market (Agarwal and Naik, 2004, and Jurek and Stafford, 2015). Moreover, hedge fund's option positions deliver abnormal future returns and reduce portfolio risk (Aragon and Martin, 2012). We test this conjecture by analyzing the sensitivity of fund firms to the Agarwal and Naik (2004) call and put option factors as well as actual disclosures of long call and put option holdings in the $13 \mathrm{~F}$ filings. Our results reveal that a fund firm's $U P$ is positively related to trading strategies involving long put options which can potentially help funds enhance performance through superior risk management.

Third, we examine if UP is associated with engagement in short-selling strategies which are shown to be highly profitable on average (see Jones, Reed, and Waller, 2016, and Jank and Smajlbegovic, 2017). Hence, we compute a fund firm's sensitivity to an aggregate short interest index (Rapach, Ringgenberg, and Zhou, 2016) and relate this sensitivity to UP. We find that the higher a fund firm's sensitivity to short interest, the higher is the fund firm's $U P$. This suggests that hedge funds with higher $U P$ measure profit from the use of short selling strategies.

Finally, we investigate the relation between $U P$ and a fund firm's trading confidentially. Fund firms can conceal certain portfolio positions that need to be revealed with a delay after the request of confidential treatment is either denied by the SEC or has expired (typically one year). Agarwal, Jiang, Tang, and Yang (2013) and Aragon, Hertzel, and Shi (2013) show that hedge funds trade confidentially on information-sensitive events to reduce price impact. As a result, confidential holdings exhibit superior future performance. We show that fund firms that disclose a large value of confidential holdings also display high $U P$. Hence, we provide empirical evidence that a fund firm's unobserved performance can partly be explained by its non-publicly disclosed portfolio positions.

Since all the four aspects of hedge funds' trading strategies - intraquarter trading, derivatives usage, short selling, and confidential trading - are suggestive of better future fund 
performance, we finally investigate whether a hedge fund firm's $U P$ is able to predict future performance. Our results from univariate portfolio sorts of fund firm's $U P$ and future performance shows that fund firms with high $U P$ perform significantly better than their peers. The difference in average returns of funds in top and bottom quintiles of $U P$ amounts to $0.53 \%$ per month for raw returns and $0.55 \%$ per month for the alpha from the nine-factor model (Fung and Hsieh (2004)'s seven-factor model augmented by the Fama and French (1993) book-to-market factor (HML) and the Carhart (1997) momentum factor). Interestingly, $U P$ predicts future fund firm performance significantly better that past fund firm performance (future risk-adjusted return spread of $0.34 \%$ ) or past performance derived from long equity positions (future risk-adjusted return spread of $-0.17 \%$ ). Furthermore, the $U P$ performance spread is not driven by the exposure to other asset classes (such as emerging market equities, bonds, and commodities) nor can be explained by differences in the exposure to other alternative risk factors like investor sentiment (Baker and Wurgler, 2006), liquidity risk (Pástor and Stambaugh, 2003), betting-against-beta (Frazzini and Pedersen, 2014), macroeonomic uncertainty (Bali, Brown, and Caglayan, 2014), correlation risk (Buraschi, Kosowski, and Trojani, 2014), volatility risk (Bondarenko, 2004; Agarwal, Bakshi, and Huij, 2009), rare disaster concerns (Gao, Gao, and Song, 2018), and tail risk (Agarwal, Ruenzi, and Weigert, 2017).

Predictability of $U P$ for future fund returns is not subsumed by other fund characteristics and holds when we control for a fund's past return, size, age, volatility, manager delta, management and incentive fees, minimum investment, lockup and redemption periods, offshore location, leverage usage, high-watermark, hurdle rate, as well as a fund's $\mathrm{R}^{2}$ measure and strategy distinctiveness (Sun, Wang, and Zheng, 2012). Predictability of UP is also stable over time, observed both in periods of high and low economic activity as well as high and low market volatility, and extends up to 12 months in the future. We also show that 
the documented outperformance of high $U P$ funds also survives a battery of additional robustness checks.

Our paper makes several contributions to the literature. First, we derive a new performance metric, $U P$, which combines information from both reported fund returns and disclosed equity portfolio holdings from hedge funds. This measure is shown to predict the cross-section of future hedge fund returns, and outperforms predictions by either returnsbased performance measures or a holdings-based performance measure. Second, we show that $U P$ is related to different fund characteristics proxying for managerial incentives, discretion, and skill. In particular, it is significantly correlated with fund manager's delta, lockup period, and the $\mathrm{R}^{2}$ measure of Titman and Tiu (2011). Third, our paper is the first to explore the trading strategies that drive unobserved performance of hedge funds for which we exploit detailed portfolio disclosures from fund firms' intraquarter long and short equity trades as well as derivatives and confidential trading. In that sense, our UP measure is different from the return gap measure of Kacperczyk, Sialm, and Zheng (2008) for mutual funds. While mutual funds predominantly use long-only buy-and-hold investment strategies, hedge funds are relatively much less constrained in their investment strategies which involve short selling, derivatives, and more dynamic trading strategies. Moreover, in contrast to Kacperczyk, Sialm, and Zheng (2008)'s return gap, we risk-adjust a hedge fund firm's unobserved component to control for exposure to non-equity asset classes and focus on the skill of the manager when engaging in these non-standard investment strategies.

The structure of the paper is as follows. Section 2 describes the data and introduces the concept of unobserved performance $(U P)$. Section 3 sheds light on the relation between funds' characteristics and UP. In Section 4, we examine trading strategies that are likely to influence $U P$. Section 5 presents empirical results on the relation between $U P$ and the cross section of future hedge fund returns. Section 6 concludes. 


\section{Data and Unobserved Hedge Fund Performance}

\subsection{Data}

We obtain the data for this study from four distinct sources. The first source is the "Union Hedge Fund Database", which contains self-reported monthly returns of hedge funds as well as a snapshot of fund characteristics. We create this union data by merging hedge fund data from four different commercial databases, namely Eurekahedge, Hedge Fund Research (HFR), Morningstar, and Lipper TASS. As our second source, we employ the 13F long equity holdings database from Thomson Reuters (formerly the CDA/Spectrum database). The third data source is the Securities and Exchange Commission's (SEC's) EDGAR (Electronic Data Gathering, Analysis, and Retrieval) database. It consists of a fund firm's long positions in call and put options as well as long equity positions that are disclosed with a delay (referred to as "confidential" by Agarwal, Jiang, Tang, and Yang, 2013), all extracted from the $13 \mathrm{~F}$ filings.

The Union Hedge Fund Database includes data for a total of 25,732 funds from 1994 to 2012. It is important to use this merging procedure to obtain a comprehensive database because $65 \%$ of all funds only report to a single database (e.g., Lipper TASS has only $22 \%$ unique funds). We display the overlap between the four databases in Figure A.1 in the Appendix. We use multiple standard filters for our sample selection. First, we start our sample period in 1994, the year in which commercial hedge fund databases started to track defunct hedge funds. Second, we require a fund to have at least 24 monthly return observations. Third, we exclude funds denoted in a currency other than US dollars. Fourth, following Kosowski, Naik, and Teo (2007), we eliminate the first 12 months of a fund's return series to mitigate the backfill bias. This filtering process leaves us with a sample of 10,834 hedge funds in the sample period from January 1994 to December 2012. 
The 13F Thomson Reuters Ownership database consists of quarterly long equity positions of 5,536 institutional investors during the period from 1980 (when Thomson Reuters data starts) to 2012. This database does not separately categorize hedge fund firms. Therefore, we follow Agarwal, Fos, and Jiang (2013) and classify hedge fund firms manually. We end up with a sample of 1,694 unique hedge fund firms among the $13 \mathrm{~F}$ filing institutions holding a total value of \$2.52 trillion of long equity positions in 2012 .

We merge the hedge fund firms from the $13 \mathrm{~F}$ database with the firms listed in the Union Hedge Fund Database. Following Agarwal, Fos, and Jiang (2013) and Agarwal, Ruenzi, and Weigert (2017), we match institutions by name allowing for minor variation. We compute for each hedge fund firm $i$ in month $t$ the reported fund firm return and equity portfolio return. Since hedge funds, and not firms, report their returns to commercial databases, we compute the reported fund firm return as the value-weighted excess returns of all the funds in a firm. Using the $13 \mathrm{~F}$ long equity positions, we compute the equity portfolio return as the value-weighted excess returns of the firm's disclosed equity positions after subtracting its hypothetical execution costs. ${ }^{4}$ To compute a fund's transaction costs, we follow Wermers (2000) and Kacperczyk, Sialm, and Zheng (2008) who estimate execution costs according to a fitted regression approach separately for the costs of buying and selling stocks. ${ }^{5}$ We consider equity portfolio returns net of costs because reported fund firm returns are also net of trading costs.

Since $13 \mathrm{~F}$ positions are reported only on a quarterly basis, we use a firm $i$ 's equity positions in month $t$ to compute the equity portfolio return over months $t+1$ to $t+3$ to obtain a

\footnotetext{
${ }^{4}$ In calculating equity portfolio returns, we do not include confidential holdings that are disclosed in later amendments (see Section 4.4).

${ }^{5}$ For the detailed regression equations for the costs of buying and selling stocks, see the Appendix in Kacperczyk, Sialm, and Zheng (2008).
} 
return series of monthly observations. ${ }^{6}$ We eliminate all pairs in which there are fewer than 24 overlapping periods of data from both data sources. Furthermore, since we are interested in hedge funds with substantial long equity exposure, we discard fund firms with a majority of CTA or Dedicated Short Bias funds. We end up with 668 hedge fund firms managing 2,295 distinct funds during the period from 1994 to 2012.

Finally, for some empirical investigations in Section 4.2 and Section 4.4, we merge our sample with quarterly $13 \mathrm{~F}$ filings of long option positions and confidential holdings of hedge fund firms in the period from April 1999 (when electronic filings become available) to December 2012 obtained from the SEC EDGAR database. The 13F filing institutions have to report holdings of long option positions on individual $13 \mathrm{~F}$ securities and provide information on whether the options are calls or puts and the underlying securities. Moreover, $13 \mathrm{~F}$ filing institutions can request confidential treatment from the SEC for certain holdings to delay disclosure. If a request is denied, or after the approval period of confidentiality expires, the filers must reveal these holdings by filing "amendments" to their original Form 13F. Following Agarwal, Jiang, Tang, and Yang, (2013), we refer to these amendments as confidential filings. Out of the 668 hedge fund firms that appear both in the Union Hedge Fund Database and in the 13F Thomson Reuters Ownership database, 320 fund firms file at least one long option position and 99 fund firms file at least one confidential position.

\subsection{Unobserved Performance}

To capture a fund firm's unobserved performance (UP), we first define its unobserved return component $(U R C)$ and then risk-adjust it by commonly used risk factors for hedge funds to isolate managerial skill. Formally, for each fund firm $i$ in month $t$, we first define the

\footnotetext{
${ }^{6}$ As an example, we use the disclosed 13F positions of a firm $i$ at the end of December 2011 to compute the equity portfolio return for the months from January 2012 to March 2012. To compute the portfolio return for the months from April 2012 to June 2012, we use the disclosed positions at the end of March 2012, and so on.
} 
unobserved return component as the difference between a fund firm's reported return and its equity portfolio return,

$$
U_{R C_{i, t}}=\text { Fund Return }_{i, t}-\text { Equity PF Return }_{i, t} .
$$

This measure is similar to the return gap measure of Kacperczyk, Sialm, and Zheng (2008) for mutual funds but as mentioned before, we need to adjust for the unique risks to which hedge funds are exposed. We report the descriptive statistics of fund firms' reported excess returns, portfolio excess returns, unobserved return components, and characteristics in Panel A of Table 1. We calculate statistics over all fund firms and months in our sample period. All variables are defined in Table A.1 of the Appendix.

[Insert Table 1 around here]

Our results indicate that, on average, the hypothetical equity portfolio return of hedge fund firms exceeds the reported fund firm return by $0.06 \%$ per month, i.e., $U R C$ is slightly negative. We also investigate the time-series variation in the different return components of hedge funds. To do so, we compute a fund firm's aggregate reported return, aggregate equity portfolio return, and aggregate unobserved return component as the monthly equalweighted average of aggregate returns, equity portfolio returns, and unobserved return components across all fund firms. Panel A of Figure 1 displays the time-series of monthly aggregate reported returns and aggregate equity portfolio returns while Panel B displays it for the aggregate unobserved return component.

\section{[Insert Figure 1 around here]}

Visual inspection shows that the time-series of aggregate equity portfolio returns is more volatile than the time-series of aggregate reported returns. We find that the highest spikes in the aggregate unobserved return component coincide with periods of financial downturns, i.e., in October 2008 (one month after the bankruptcy of Lehman Brothers and the 
beginning of a worldwide recession, value of 10.71\%), August 1998 (Asian Financial Crisis with the collapse of Long Term Capital Management, value of 9.04\%), and September 2001 (burst of the dotcom bubble, value of $8.34 \%$ ), suggesting that unobserved actions of hedge fund firms are particularly valuable and informative during crisis periods. To the contrary, the lowest observations in the aggregate unobserved return component occur in April 2009 $(-9.48 \%)$, October $2011(-9.19 \%)$, and March 2009 (-6.73\%), periods characterized by high equity market returns.

To determine the components of hedge fund returns that are associated with superior risk-adjusted performance, we estimate time-series regressions of aggregate reported returns, aggregate equity portfolio returns, and aggregate unobserved return components measured in month $t$ on the risk factors of Fung and Hsieh (2004)'s seven-factor model (i.e., $S \& P$, SCMLC, BDIORET, BAAMTSY, PTFSBD, PTFSFX, and PTFSCOM) augmented by the Fama and French (1993) book-to-market factor $(H M L)$ and the Carhart (1997) momentum factor $(U M D)$, also measured in month $t$. Standard errors are adjusted for serial correlation using the Newey and West (1987) correction over 36 lags. Results are shown in Panel B of Table 1.

Compared to the results of average raw returns, we find that - when accounting for hedge fund risk factors - the alpha for aggregate reported returns $(0.316 \%$ per month, $t$ statistic of 3.31) is substantially higher than the alpha for aggregate equity portfolio returns $(0.032 \%$ per month, $t$-statistic of 0.36$)$. Hence, our results reveal that overall hedge fund alpha seems to (almost) entirely stem from the funds' unobserved actions $(0.291 \%$ per month, $t$-statistic of 3.76). Furthermore, we find that the aggregate unobserved return component has significant negative loadings on the S\&P 500 market factor, the small-minus-big SCMLC factor, and the HML factor, while loadings on the BAAMTSY and UMD factors are significantly positive. 
Based on this first set of findings, we now define our main measure of the empirical analysis, a fund firm's Unobserved Performance (UP). It is defined as the difference between a fund firm's performance based on its reported return series (Fund Performance) and a fund firm's performance based on its long equity portfolio (Equity Portfolio Performance). We adjust both these performance measures for the nine risk factors mentioned above. In each case, we apply a rolling window of 36 months for the estimation of factor loadings. Formally, for each fund firm $i$ in month $t$, we define:

$$
U P_{i, t}=\text { Fund Performance }_{i, t}-\text { Equity PF Performance }_{i, t} \text {. }_{\text {P }}
$$

with

$$
X \text { Performance }_{i, t}=X \text { Return }_{i, t}-X \text { Return }_{i, t, \text { expected }} .
$$

and

$$
\begin{gathered}
X \text { Return }_{i, t, \text { expected }}=\hat{\beta}_{1, i, t} \operatorname{S\& P} P_{t}+\hat{\beta}_{2, i, t} \text { SCMLC }_{t}+\hat{\beta}_{3, i, t} \text { BDIORET }_{t}+\hat{\beta}_{4, i, t} \text { BAAMTSY } \\
\hat{\beta}_{5, i, t} \text { PTFSBD }_{t}+\hat{\beta}_{6, i, t} \text { PTFSFX }_{t}+\hat{\beta}_{7, i, t} \text { PTFSCOM }_{t}+\hat{\beta}_{8, i, t} \text { HML }_{t}+\hat{\beta}_{9, i, t} \text { UMD }_{t},
\end{gathered}
$$

with $X \in\{F$ und, Equity $P F\}$. Therefore, $U P$ captures the performance of a hedge fund firm's unobserved components that are not captured by the performance of its disclosed long equity portfolio positions. Fund firms with high $U P$ strongly deviate from their disclosed long equity risk-adjusted portfolio returns while risk-adjusted reported returns of fund firms with low $U P$ are similar to their equity portfolio counterpart. Our $U P$ measure is related to the return gap measure in Kacperczyk, Sialm, and Zheng (2008). However, unlike mutual funds, hedge funds use dynamic trading strategies often involving derivatives, short selling, 
and leverage. Therefore, the UP measure not only captures the intraquarter trading as in the case of mutual funds but also reflects the distinctive nature of hedge funds' investment strategies in terms of the use of derivatives and short selling as well as positions that are not immediately disclosed in their $13 \mathrm{~F}$ filings. In the next section, we will provide a detailed analysis of these constitutents of the $U P$ measure.

We report summary statistics of Fund Performance, Equity Portfolio Performance, and Unobserved Performance (UP) in Panel $\mathrm{C}$ of Table 1. Average Fund Performance is $0.27 \%$ per month across all funds and months in the sample, whereas Equity Portfolio Performance and UP averages are $0.06 \%$ and $0.22 \%$, respectively. Hence, as in Panel B, we observe that, after adjusting for standard hedge fund risk factors, funds' performance almost entirely comes from their unobserved performance component. UP is fairly constant across different hedge fund styles with few exceptions: $0.13 \%$ and $0.16 \%$ per month for Global Macro and Event Driven styles, and $0.33 \%$ for Sector style. The style with the highest number of different fund firms is Long-Short Equity (333 fund firms) and displays an average $U P$ of $0.21 \%$ per month, a number that is almost identical to the average $U P$ of the overall sample.

Correlations between $U P$ as well as Fund Performance, Equity Portfolio Performance, and other fund firm characteristics are reported in Panel D of Table 1. We find that $U P$ is positively correlated with a fund firm's reported return $(+0.44)$, but negatively correlated to a fund firm's equity portfolio performance $(-0.61)$. Hence, fund firms that show high returns on the unobserved components, tend to do badly on their long equity part of the portfolio. In addition, our results reveal that $U P$ has a positive relation with the manager's delta, lockup period, offshore location, leverage usage, hurdle rate, and a fund firm's strategy distinctiveness index. It reveals a negative relation with a fund firm's $\mathrm{R}^{2}$ in the augmented 
Fung and Hsieh (2004) nine-factor model. We will now analyze and discuss the relation between $U P$ and fund firm characteristics.

\section{UP and Fund Characteristics}

Results from Panel $\mathrm{C}$ in Table 1 indicate that the outperformance of hedge funds is virtually entirely driven by its $U P$. To better understand the sources of this outperformance, we now examine the fund firm characteristics associated with high $U P$. For this purpose, we estimate the following regression of $U P$ of hedge fund firm $i$ in month $t+1$ on different fund firm characteristics measured in month $t$ using the Fama and MacBeth (1973) methodology:

$$
U P_{i, t+1}=\alpha+\beta X_{i, t}+\varepsilon_{i, t+1}
$$

where $U P_{i, t+1}$ denotes fund firm $i$ 's UP in month $t+1$, and $X_{i, t}$ is a vector of fund firm characteristics.. To adjust the standard errors for potential serial correlation, we again use the Newey and West (1987) adjustment with 36 lags. Table 2 reports the results.

\section{[Insert Table 2 here]}

In column (1), we include time-varying fund firm characteristics such as the past monthly return, fund firm size, age, standard deviation, and manager delta. We define all variables in Table A.1 of the Appendix. Column (2) investigates the association between $U P$ and time-invariant characteristics, such as a fund firm's management and incentive fees, minimum investment amount, lockup and restriction periods, as well as indicator variables that equal one if the fund firm is an offshore fund, employs leverage, has a high-water mark and a hurdle rate. In column (3), we pool the time-varying and time-invariant variables, and in column (4), we also add the $\mathrm{R}^{2}$ measure of Titman and Tiu (2011), and the strategy distinctiveness (SDI) measure of Sun, Wang, and Zheng (2012). 
In columns (1) to (4), we observe the following patterns. First, small funds typically display high $U P$. This finding is in line with the previous hedge fund literature (see e.g., Aggarwal and Jorion, 2010) who find that small funds are more nimble and face less capacity constraints compared to large funds. Second, fund firms with high $U P$ are positively associated with measures of managerial incentives such as manager delta, management fee, offshore location, and the existence of a hurdle rate. Therefore, better incentivized managers tend to invest outside the disclosed long equity holdings and show higher $U P$. Third, our results reveal that high $U P$ fund firms display high managerial discretion, which we proxy by a fund firm's lockup and restriction periods, and leverage. Finally, we uncover that fund firms with high $U P$ show low $\mathrm{R}^{2}$ from the nine-factor model. This finding is intuitive in the sense that high $U P$ fund managers do not seek a strong factor exposure and show confidence in their abilities to generate abnormal returns from the active component of their portfolios.

The findings from this section show that the positive, abnormal UP return spread is not random and can be traced back to several distinct fund characteristics, most of which are associated with better fund performance. These findings indicate that $U P$ is likely to reflect managerial skill. In the following section, we dig deeper and examine the trading channels that are correlated with a fund firm's UP to uncover the drivers of managerial skill in hedge funds.

\section{UP and Different Trading Channels}

We investigate four potential trading channels that might influence a fund firm's $U P$. Section 4.1 examines whether $U P$ is related to intraquarter trading of long-equity positions, while Section 4.2 investigates the association between $U P$ and fund firms' derivatives usage. In Section 4.3, we relate fund firms' UP with engagements in short-selling activities. Finally, we analyze the link between $U P$ and fund firms' confidential trading in Section 4.4. 


\subsection{Active Trading in Long Equity Positions}

The hedge fund fund firms in our sample disclose long equity positions to the SEC on a quarterly frequency. However, fund firms' intraquarter transactions, i.e., buys and sells that take place within a quarter, are typically not revealed to the public. Based on our definition of the $U P$ measure (as the risk-adjusted difference between a fund firm's reported return and the return of its disclosed quarterly equity holdings), there is potentially a significant link between a fund firm's $U P$ and interim trading engagement.

Several academic studies investigate the relation between active trading and performance. While the link is shown to be significantly negative for individual investors (see Barber and Odean, 2000), mixed performance results are found for institutional investors (such as mutual funds and hedge funds). While Bennett, Sias, and Starks (2003), Cai and Zheng (2004), and Yan and Zhang (2009) find conflicting results on whether institutional trading predicts future stock returns, Chen, Jegadeesh, and Wermers (2000), Kacperczyk, Sialm, and Zheng (2005), and Alexander, Cici, and Gibson (2007) observe that the stocks that mutual funds purchase earn significantly higher returns than the stocks they sell. Moreover, using a large proprietary database of institutional trades, Puckett and Yan (2011) find strong evidence that institutions earn significant abnormal returns on their trades within the trading quarter.

Panel A of Table 3 investigates the relation between $U P$ and a proxy for interim trading in our full data sample. For this purpose, we define fund firm i's portfolio turnover in month $t$ as the total of its stock purchases and sales in month $t$ divided by 2 , divided by its total equity portfolio market capitalization in month $t-1 .^{7}$

[Insert Table 3 here]

\footnotetext{
${ }^{7}$ Our measure takes account of the total of stocks purchased and sold by the fund firm in month $t$. Our results between portfolio turnover and UP (as reported in Panel A of Table 3) are very similar when we compute the turnover measure base on pure buying or pure selling transactions.
} 
Column (1) shows the results of a regression of $U P$ in month $t+1$ on a fund firm's portfolio turnover in month $t$. We find that the coefficient estimate of portfolio turnover is 0.152 and statistically significant at the $5 \%$ level. Based on this estimate, a one standard increase in portfolio turnover implies a higher $U P$ of $0.07 \%$ per month. In column (2), we expand our model to control for different portfolio characteristics. Specifically, we add a fund firm's number of different stock positions, the portfolio's Herfindahl index (as a measure of portfolio concentration), size, beta, illiquidity (measured by the Amihud (2002) ratio), and book-to-market ratio in month $t$ to our model. All control variables are based on disclosed holdings. Our results reveal that the relation between $U P$ and portfolio turnover remains positive and statistically significant at the $10 \%$ level. No other portfolio control variables show a significant relationship with $U P$.

\subsection{Derivatives}

Hedge funds are known to employ derivatives in their trading strategies. Agarwal and Naik (2004) show that a large number of equity-oriented hedge fund strategies exhibit payoffs resembling a short position in a put option on the market index, and Agarwal, Ruenzi, and Weigert (2017) show that a main part of hedge fund's tail risk is driven by dynamic trading strategies that mimic the return of selling out-of-the money put options. Using detailed disclosures of equity option positions of hedge fund advisors to the SEC, Aragon and Martin (2012) find that option positions predict both volatility and returns on the underlying stocks, and that a quarterly tracking portfolio of stocks based on publicly observable hedge fund option holdings earns abnormal returns of $1.55 \%$ per quarter. We therefore hypothesize that derivative holdings of hedge funds should also influence the UP measure.

We start to investigate the relation between derivatives exposure and $U P$ in our full sample from 1994 to 2012. To do so, we estimate funds' exposure to the Agarwal and Naik 
(2004) out-of-the money (OTM) call option and put option factors. These factors are constructed by computing the return of a strategy that involves buying OTM call and put options on the S\&P composite index with two months to maturity at the beginning of each month and selling them at the beginning of the next month.

We estimate a fund firm $i$ 's univariate exposures to the OTM call and put option factors using a rolling window of 36 monthly returns. In the second step, we estimate the following Fama and MacBeth (1973) regressions at the individual fund level of UP in month $t+1$ on the OTM call and put option factor sensitivities in month $t$ :

$$
U P_{i, t+1}=\alpha+\lambda_{1} \hat{\beta}_{\text {OTMCall,t }}+\lambda_{2} \hat{\beta}_{\text {OTMPut }, t}+\varepsilon_{i, t+1}
$$

To adjust the standard errors for serial correlation, we use the Newey and West (1987) adjustment with 36 lags. Since we perform a two-step estimation procedure, we correct the standard errors for the errors-in-variables problem using the Shanken (1992) correction. Panel A of Table 4 reports the results.

\section{[Insert Table 4 here]}

In column (1), we regress $U P$ on the sensitivity of the OTM-call option factor and do not find a significant relation. Column (2) investigates the link between $U P$ and a fund firm's sensitivity to the OTM-put option factor. We find a significantly positive relation between $U P$ and $\beta_{\text {OтMPut }}$ with a coefficient estimate of 3.859 and a $t$-statistic of 2.15 . In economic terms, this implies an increase in $U P$ of $0.11 \%$ for a one standard deviation increase in $\beta_{\text {OTMPиt }}$. In column (3), we regress UP on both $\beta_{\text {OTMPиt }}$ and $\beta_{\text {OTMPиt }}$ and continue to find a significant and positive link between $U P$ and the fund firm's sensitivity to the OTM-put option factor. Finally, in column (4), we replace a fund firm's sensitivities to the OTM call option and put option factors with the corresponding sensitivities to the at-the-money (ATM) call option and put option factors. Our results are similar to column (3). We observe (i) no 
significant relation between $U P$ and the call option factor, but a (ii) significant positive relation between $U P$ and a fund firm's exposure to put options.

In addition to investigating the relation between $U P$ and fund firms' sensitivities to aggregate option returns, we also examine actual disclosed option data from hedge fund firms. For this purpose, we use long call and put option holdings data from the $13 \mathrm{~F}$ filings in the SEC EDGAR database during the sample period from April 1999 to December 2012. We find that during this period, $47.9 \%$ of firms (i.e., 320 of 668 firms) file at least one long option position. To merge fund firms that disclose their derivative positions quarterly with monthly $U P$ estimates, we again apply the convention that disclosed positions in month $t$ are carried forward for the subsequent months $t+1$ to $t+3$. We then compute for hedge fund firm $i$ in month $t$, (i) the number of different stocks on which funds hold call and put positions, (ii) the equivalent number of equity shares underlying these positions (in millions), and (iii) the equivalent value of equity shares underlying these positions (in millions). ${ }^{8}$ To mitigate the influence of outliers, we winsorize the number and value of equity shares at the $1 \%$ level. We observe that the average number of different stocks on which call (put) positions are held is 2.80 (2.86), the number of equity shares underlying the put (call) positions is 1.10 (1.02) million, and the value of equity shares underlying the put (call) positions is $\$ 14.59$ (\$14.66) million.

We regress $U P$ of hedge fund firm $i$ in month $t+1$ on the number of different stocks on which funds hold call and put positions, as well as the natural logarithms of one plus the equivalent number of equity shares underlying these call and put positions and the equivalent

\footnotetext{
${ }^{8}$ To illustrate these measures, we provide the following example: A fund firm holds call options on 10,000 shares of stock A that trades at \$20 and 5,000 shares of stock B that trades at \$30. It holds put options on 20,000 shares of stock $\mathrm{C}$ that trades at $\$ 40$. Then, (i) the number of stocks on which call options are held is 2 and the number of stocks on which put options are held is 1 , (ii) the equivalent number of equity shares underlying the call options is 15,000 and the equivalent number of equity shares underlying the put options is 20,000 , and (iii) the equivalent value of equity shares underlying the call options is 350,000 and the equivalent value of equity shares underlying the put options is $\$ 800,000$.
} 
value of equity shares underlying these call and put positions in month $t$ using the Newey and West (1987) adjustment with 36 lags. ${ }^{9}$ We display the results in Panel B of Table 4.

In columns (1) through (3), UP is regressed on the number of different call and put options, the number of shares underlying these call and put options, and the value of shares underlying these call and put options, respectively. Consistent with our findings in Panel A, we observe that all explanatory variables that are related to put options significantly increase a fund firm's $U P$, whereas we do not find any significant impact of the call options. In column (4), we estimate a multivariate regression of $U P$ on all explanatory variables. In this setting, we observe significantly positive relations between $U P$ and the number of different stocks on which funds hold put positions and between $U P$ and the equivalent value of equity shares underlying these put positions. In terms of economic significance, we find that a one standard deviation increase in the number of put options (value of shares underlying the put options) enhances a fund firm's $U P$ by $0.10 \%(0.09 \%)$.

Overall, these results provide evidence that derivatives usage of hedge fund firms, in particular, long put option usage, is an important channel that affects a fund firm's $U P$. These results are in line with previous findings of the literature that document superior risk management skills of hedge fund managers in tail risk strategies (see Agarwal, Ruenzi, and Weigert, 2017) and merger arbitrage strategies (see Cao, Goldie, Liang, and Petrasek, 2018).

\subsection{Short-Selling}

The recent academic literature observes that short-selling strategies yield abnormal profits on average. Jones, Reed, and Waller (2016) find that large short positions in the European Union earn statistically significant 90-day cumulative abnormal returns of $5.23 \%$ and seem to be informed. Jank and Smajlbegovic (2017) document that hedge funds, the

\footnotetext{
${ }^{9}$ We logarithmically transform equivalent number of equity shares underlying these call and put positions and equivalent value of equity shares underlying these call and put positions to reduce the skewness of the variables and make them conform more closely to the normal distribution.
} 
predominant short sellers on financial markets, earn an annualized Fama-French risk-adjusted return of $5.5 \%$ on their disclosed short positions. The profitability of short positions is also confirmed by Beschwitz, Lunghi, and Schmidt (2017) when evaluating detailed hedge fund transaction data. Hence, it is possible that $U P$ is connected to a fund firm's short-selling activities and a part of the UP return spread is related to the profitability of short positions.

We investigate the relation between $U P$ and short-selling activity during our sample period from 1994 to 2012. As there is no direct data on the short selling activities for the hedge fund firms in our sample, we instead estimate funds' exposure to the relative changes in the aggregate short interest index of Rapach, Ringgenberg, and Zhou (2016). ${ }^{10}$ The aggregate short index is constructed as a monthly time series by calculating the equallyweighted average of short interest (as a percentage of shares outstanding) across all publicly listed stocks on the US exchanges available in Compustat.

We estimate a fund firm $i$ 's univariate exposure to the changes in the aggregate short interest index using a rolling window of 36 monthly returns. We next estimate Fama and MacBeth (1973) regressions at the individual fund level of $U P$ in in month $t+1$ on the aggregate short interest sensitivity in month $t$ :

$$
U P_{i, t+1}=\alpha+\lambda_{1} \hat{\beta}_{\text {Shorthteest }, t}+\varepsilon_{i, t+1} .
$$

To adjust the standard errors for serial correlation, we use the Newey and West (1987) adjustment with 36 lags. To correct for the the errors-in-variables problem in a two-step estimation procedure, we use the Shanken (1992) correction. Panel A of Table 5 reports the results.

\section{[Insert Table 5 here]}

\footnotetext{
${ }^{10}$ Data for this index (and additional subindices) is obtained from the webpage of Matthew Ringgenberg.
} 
Column (1) shows the results of the univariate regression of UP in month $t+1$ on a fund firm's sensitivity to the aggregate short interest index. We find a coefficient estimate of 0.308 which is statistically significant at the $5 \%$ level. Hence, fund firms that show a high sensitivity to the aggregate short index (i.e., are likely to invest in short positions) have a high $U P$. In terms of economic significance, we find that a one standard deviation increase in $\beta_{\text {Shortlnterst }}$ leads to an average UP increase of $0.08 \%$ per month. In column (2), we add different portfolio characteristics to our model, namely a fund firm's number of different stock positions, the portfolio's Herfindahl index (as a measure of portfolio concentration), size, beta, illiquidity (measured by the Amihud (2002) ratio), and book-to-market ratio (as in column (2) in Panel A of Table 3). Our results reveal that the association between UP and $\beta_{\text {Shortlnterst }}$ is stable and remains statistically significant at the 5\% level even after controlling for other portfolio characteristics in the multivariate analysis.

\subsection{Confidential Holdings}

Finally, another potential channel that influences a fund firm's UP is fund's request for confidential treatment of certain portfolio holdings. If the request is denied or after the approval period of confidentiality expires, filers must reveal these holdings by filing "amendments" to their original Form 13F. However, these amendments are not shown in the Thomson Reuters $13 \mathrm{~F}$ data and are not included in our imputed equity portfolio return of fund firms.

Confidential holdings of institutional investors (particularly hedge funds) have already been investigated in Agarwal, Jiang, Tang, and Yang (2013) and Aragon, Hertzel, and Shi (2013). Both studies find that stocks in these holdings are disproportionally associated with information-sensitive events and greater information asymmetry, as well as share characteristics that make them more susceptible to front-running. Furthermore, confidential 
holdings allow institutions to reduce price impact and earn significantly positive abnormal returns over the post-filing confidential period up to twelve months into the future. Hence, it is likely that fund firms that file a substantial amount of confidential holdings have high $U P$.

We retrieve confidential holdings data from $13 \mathrm{~F}$ filings in the SEC EDGAR database in the sample period from April 1999 to December 2012. During this time period, $14.8 \%$ of firms (i.e., 99 of 668 firms) file at least one confidential position. In the same way as for derivatives holdings, we apply the convention that disclosed positions in month $t$ are carried forward for the subsequent months $t+1$ to $t+3$. We compute for hedge fund firm $i$ in month $t$, (i) the number of different confidential positions, (ii) the equivalent number of equity shares underlying these positions (in millions), and (iii) the equivalent value of equity shares underlying these positions (in millions). To mitigate the influence of outliers, the number and value of equity shares is winsorized at the $1 \%$ level. We obtain that the average number of confidential positions is 0.44 , the number of equity shares underlying the confidential positions is 0.20 million, and the value of equity shares underlying the confidential positions is $\$ 6.59$ million. $^{11}$

We regress $U P$ of hedge fund firm $i$ in month $t+1$ on the number of different confidential positions, as well as the natural logarithms of one plus the equivalent number of equity shares underlying these positions and the equivalent value of equity shares underlying these positions in month $t$ using the Newey and West (1987) adjustment with 36 lags. Table 6 reports the results.

\section{[Insert Table 6 here]}

In columns (1) through (3), we look at the univariate relation between $U P$ and the number of different confidential positions, the equivalent number of equity shares underlying these

\footnotetext{
${ }^{11}$ These averages are computed over all hedge fund firms and months in the sample period. Conditional on a fund firm filing confidentially, the average number of confidential positions is 24.51 , the number of equity shares underlying the confidential positions is 11.21 million, and the value of equity shares underlying the confidential positions is $\$ 429.14$ million.
} 
positions, and the equivalent value of equity shares underlying these positions. Our results indicate that all variables significantly increase $U P$ in the univariate regressions. In column (4), we estimate a multivariate regression of $U P$ on the three explanatory variables. We observe significant relation between $U P$ and the equivalent number or value of equity shares underlying these confidential positions. In terms of economic significance, we find that a one standard deviation increase in the equivalent number (value) of equity shares underlying the confidential positions increases a fund firm's $U P$ by $0.13 \%(0.07 \%)$. These findings suggest that confidential holdings are an important channel that influences a fund firm's $U P$. Moreover, our results are consistent with the findings of Agarwal, Jiang, Tang, and Yang (2013) and Aragon, Hertzel, and Shi (2013), who show that confidential holdings earn abnormal future returns and therefore improve the future performance of hedge fund firms.

\section{UP and Future Hedge Fund Returns}

Our results so far show that UP is associated with hedge funds' use of intraquarter trading, derivatives, short selling, and confidential trading. These attributes of trading have been previously shown to be positively related to future fund performance. Therefore, UP should reflect managerial skill and reliably predict future fund performance, an issue we investigate in this section.

\subsection{Univariate Portfolio Sorts}

To assess the predictive power of differences in a fund firm's unobserved performance on the cross section of future fund firm returns, we relate the $U P$ measure in month $t$ to fund firm returns and alphas in month $t+3$. We leave out three months to account for the effect of serial autocorrelation in hedge fund returns (see Getmansky, Lo, and 
Makarov, 2004) and to allow for a practical implementation of the predictive strategy after accounting for lockup and redemption restrictions. ${ }^{12}$

We start our investigation by looking at univariate portfolio sorts. For each month $t$, we sort fund firms into quintile portfolios based on the UP measure in increasing order. We then compute equally-weighted monthly average excess returns of these portfolios in month $t+3$. Panel A of Table 7 reports the results. We also show the results of univariate portfolio sorts based on Fund Performance and Equity Portfolio Performance for the sake of comparison. It is important to note here that we control for risk factors explaining both these performance measures, and use alphas instead of raw returns for the univariate sorts.

\section{[Insert Table 7 around here]}

Column (3) in Panel A shows that there is a strong positive relation between $U P$ and future average returns. Hedge fund firms in the portfolio with the lowest (highest) UP earn future returns of $0.34 \%(0.87 \%)$ in excess of the risk-free rate. The return spread between portfolios 1 and 5 is $0.53 \%$ per month, which is statistically significant at the $1 \%$ level with a $t$-statistic of 4.79. We compare these findings with portfolio sorts based on Fund Performance (column 1) and Equity Portfolio Performance (column 2) and show that the respective spreads between portfolios 1 and 5 amount to $0.34 \%$ ( $t$-statistic of 2.91) and $-0.13 \%$ ( $t$-statistic of -1.41 ) per month. Finally, in column 4 , we also document that the $5-1$ differences in returns between forecasts based on UP and Fund Performance are also statistically significant at the 5\% level. These findings suggest that UP is a better predictor of future hedge fund returns in the cross section compared to Fund Performance and Equity Portfolio Performance. To further illiustrate this point, we display the cumulative returns of hypothetical trading strategies based on (i) Fund Performance, (ii) Equity Portfolio Performance, and (iii) UP in Figure 2. For each strategy we go long (short) the quintile of

\footnotetext{
${ }^{12}$ We obtain very similar results when we unsmooth hedge fund returns using Getmansky, Lo, and Makarov (2004)'s methodology or evaluate future fund firm returns in month $t+1$ or $t+2$ (see our robustness checks in Section 5.4).
} 
hedge funds with the highest (lowest) realizations of the respective sorting criteria and apply monthly rebalancing without accounting for trading costs. We assume an investment of $\$ 100$ at the beginning of 1997 (i.e., at the end of the first estimation of the performance metrics based on a horizon of 36 months).

[Insert Figure 2 around here]

Similar to the results of the univariate portfolio sorts in Panel A of Table 7, we observe that a trading strategy based on $U P$ strongly outperforms the two competing strategies based on Fund Performance and Equity Portfolio Performance. At the end of the year 2012 , the final wealth of the investor amounts to $\$ 265.20$ when pursuing the UP strategy and is substantially higher than $\$ 182.95$ and $\$ 79.04$ from the two competing strategies. We acknowledge that even though it is not feasible to short hedge funds, this analysis nonetheless demonstrates the superior predictability of UP measure relative to returns-based or holdingsbased performance measures. Furthermore, the strong outperformance of high UP funds can also be realized based on a long-only strategy.

Panel B of Table 7 reports the results when we adjust future fund firm returns by the augmented nine-factor model. As before, we document that UP is superior in predicting future risk-adjusted returns (or alphas) in comparison to Fund Performance and Equity Portfolio Performance. Hedge fund firms in the portfolio with the lowest UP earn future alphas of $0.09 \%$ per month, whereas fund firms in the portfolio with the highest UP earn future alphas of $0.64 \%$ per month. The spread between alphas of portfolios 1 and 5 is $0.55 \%$ per month, which is statistically significant at the $1 \%$ level with a $t$-statistic of 4.14 . Therefore, the return spread between hedge fund firms with high $U P$ and low $U P$ amounts to $6.60 \%$ per annum even after adjusting for exposures to the traditional hedge fund risk factors, i.e., S\&P, SCMLC, BDIORET, BAAMTSY, PTFSBD, PTFSFX, PTFSCOM, HML, and UMD. This effect is more than $50 \%$ stronger than the alpha spread between the best and worst 
performance quintiles based on reported fund firm returns and also statistically significantly different (as shown in column 4).

Can the return spread based on $U P$ be explained by additional hedge fund risk factors or funds' exposure to other asset classes? We address this question in Table 8, where we regress the high minus low $(5-1) U P$ return spread on additional risk factors (Panel A) and the returns from other asset classes (Panel B).

[Insert Table 8 around here]

To allow for the ease of comparison, in column (1) of Panel A, we report the results of the nine-factor model as our baseline specification. We include the Pástor and Stambaugh (2003) traded liquidity factor to control for liquidity exposure of fund firms in column (2). Column (3) adds the Frazzini and Pedersen (2014) betting-against-beta factor to our model. In columns (4) to (7), we control for the exposures to the Bali, Brown, and Caglayan (2014) macroeconomic uncertainty factor, Buraschi, Kosowski, and Trojani (2014) correlation risk factor, Agarwal, Bakshi, and Huij (2009) volatility risk factor (VIX), and the Gao, Gao, and Song (2018) RIX factor, respectively. Finally, in column (8), we add the Agarwal, Ruenzi, and Weigert (2017) factor to our model to account for hedge funds' tail risk. In each case (except for column 6), we observe a negative loading on the market factor and a positive loading on the $H M L$ factor. Moreover, our results indicate a significant positive alpha for the high minus low $(5-1) U P$ return spread ranging from $0.52 \%$ to $0.57 \%$ per month.

Panel B of Table 8 investigates whether the UP return spread is due to hedge funds' exposure to other asset classes. After repeating our basic specification in column (1), we extend it by adding returns of the MSCI Emerging Market index, the Barclays US Aggregate Bond index, and the S\&P GSCI Commodities index in columns (2) to (4). Again, we find that the inclusion of these factors does not reduce the statistical and economic significance of the $U P$ return spread. 
To summarize, we find that a fund firm's unobserved performance $(U P)$, computed as the difference between a fund firm's reported performance and equity portfolio performance, is a strong predictor for the cross section of future average hedge fund returns. In particular, it is superior in predicting future fund returns compared to either a fund firm's reported performance or its equity portfolio performance. We also show that the return spread based on $U P$ is not subsumed by different hedge fund risk factors and not explained by fund firms' investments in emerging market equity, bonds, and commodities.

\subsection{Bivariate Portfolio Sorts}

The return spread based on $U P$ could be potentially driven by its core building blocks, Fund Performance and Equity Portfolio Performance. In line with this idea, we find (as noted in Panel D of Table 1) that the correlations between UP and Fund Performance (+0.44), and between UP and Equity Portfolio Performance (-0.61) are high in absolute values. To distentangle the $U P$ return spread from the two performance variables, we perform portfolio double sorts based on (i) Fund Performance and UP, as well as (ii) Equity Portfolio Performance and UP. Results are displayed in Table 9.

[Insert Table 9 around here]

We first conduct dependent portfolio double sorts based on Fund Performance and $U P$. For this purpose, we form quintile portfolios sorted on Fund Performance. Then, within each Fund Performance quintile, we sort fund firms into five portfolios based on UP (both sorts taking place in month $t$ ). We report the equally-weighted average returns of the 25 Fund Performance $\times U P$ portfolios in Panel A. Our results reveal that fund firms with high $U P$ have higher returns than fund firms with low UP in all Fund Performance quintiles with statistically significant return spreads in three out of five quintiles. The average spread in returns between high UP and low UP firms after controlling for Fund Performance amounts 
to $0.35 \%$ per month and is statistically significant at the $5 \%$ level. The last row in Panel A shows that we obtain similar results when we report nine-factor alphas instead of raw returns.

Second, we conduct dependent portfolio double sorts based on Equity Portfolio Performance and $U P$ using the same methodology. We observe that high $U P$ fund firms outperform low UP fund firms in all Equity Portfolio Performance quintiles with statistically significant return spreads in four out of five Equity Portfolio Performance quintiles. The average UP spread after controlling for Equity Portfolio Performance amounts to $0.53 \%$ per month and is statistically significant at the $5 \%$ level. When we evaluate differences in ninefactor alphas, we obtain almost identical results (spread of $0.52 \%$ per month which is statistically significant at the 5\% level).

In summary, we find that the risk-adjusted return spread based on UP cannot be explained by fund firm differences in Fund Performance and Equity Portfolio Performance.

\subsection{Multivariate Evidence}

To simultanously control for several control variables when investigating the impact of $U P$ on future fund firm returns, we estimate Fama and MacBeth (1973) regressions of future fund returns in month $t+3$ on $U P$ and fund characteristics in month $t$ :

$$
r_{i, t+3}=\alpha+\beta_{1} U P_{i, t}+\beta_{2} X_{i, t}+\varepsilon_{i, t+3},
$$

where $r_{i, t+3}$ denotes fund firm $i$ 's reported return in month $t+3, U P_{i, t}$ is a fund firm's unobserved performance, and $X_{i, t}$ is a vector of fund firm characteristics. We use the Newey and West (1987) adjustment with 36 lags to adjust standard errors for potential serial correlation. In terms of fund characteristics, we include a fund's past return, size, age, volatility, manager delta, management and incentive fees, minimum investment, lockup and restriction (i.e., sum of redemption and notice) periods, indicator variables for a fund's 
offshore location, leverage usage, high-watermark, hurdle rate, as well as a fund's $\mathrm{R}^{2}$ measure and strategy distinctiveness. Panel A of Table 10 reports the results.

[Insert Table 10 around here]

Our results indicate that controlling for various fund characteristics at the same time, the impact of $U P$ on future fund firm returns and alphas is positive and statistically significant in all specifications. Depending on the specification, the coefficient estimate of $U P$ ranges from 0.0229 to 0.0545 when we use future returns as the dependent variable, and is 0.0478 in column (6) with future alpha as the dependent variable. Hence, given a standard deviation of 3.05 for $U P$ over our sample, a one standard deviation increase in $U P$ is associated with an annualized increase in future fund firm returns (and alphas) between $0.83 \%$ and $1.99 \%$. In addition to our main result of a positive impact of $U P$ on future fund performance, we confirm a set of different empirical results from the hedge fund literature. Specifically, we find that a fund's volatility, delta, lockup and restriction periods, offshore location, and hurdle rate have a positive relation with future performance, while fund size is associated with lower future performance.

In columns (1) to (6) of Panel B in Table 10, we examine the predictive power of $U P$ on future alphas in different states of the world and across different time periods. We use the identical specification as in column (6) of Panel A, but only report the coefficient estimates of $U P$ for the sake of brevity. We find that the impact is statistically significant during periods of both high and low economic activity (as measured by the Chicago FED National Activity Index, $C F N A I$ ). The alphas associated with $U P$ are statistically significant in periods of high and low volatility; however, the economic impact of $U P$ is substantially stronger for the high volatility state. This finding highlights that the unobserved component of a hedge fund's strategy does pay off particularly in volatile times. Finally, our results indicate that the impact 
of $U P$ on future fund firm alphas is strong in both subperiods from 1994-2003 and 2004-2012.

Until now, we have investigated the ability of $U P$ in month $t$ to predict future fund returns and alphas in month $t+3$. A natural question is how the relation between $U P$ and future performance alters when we use fund firm alphas in different months and how far in the future this relation persists. This question is particularly important to investors who aim to invest in high $U P$ hedge fund firms: the majority of hedge funds in our sample employ lockup and restriction periods, and actual long equity portfolio holdings of hedge fund firms are not immediately observable to investors as regulation allows for a disclosure delay of 45 days after quarter ends. Therefore, investors can only construct and rebalance their portfolios with a delay. Panel $\mathrm{C}$ reports the results of regressions of future fund firm alphas in month $t+3$ (baseline scenario), $t+1, t+2, t+6$, and $t+12$. Again, we use a specification identical to column (6) of Panel A, but only report the coefficient estimate of UP for brevity. We find that $U P$ can significantly predict future fund firm returns up to twelve months into the future. Hence, we find strong evidence that investors can use the UP measure to select hedge funds that are likely to perform well in the future, even if long equity positions are disclosed with a delay. $^{13}$

\subsection{Robustness Checks}

To confirm the results concerning $U P$ and future fund firm performance, we conduct a battery of robustness checks. For this purpose, we examine the stability of our results by (i) using value-weighted hedge fund firm portfolios instead of equally-weighted portfolios, (ii) using only hedge fund firms with a single fund, (iii) restricting our sample to hedge fund firms with an equity long-short strategy, (iv) assigning a delisting return of $-1.61 \%$ as in

\footnotetext{
${ }^{13}$ Note, however, that the performance of a potential trading strategy based on $U P$ will suffer from substantial transaction costs which we do not take into account in this study.
} 
Hodder, Jackwerth, and Kolokolova (2014) to those hedge funds that leave the database, and (v) using the Getmansky, Lo, and Makarov (2004) methodology to unsmooth the returns of hedge fund firms. Panel A of Table 11 report the results from univariate portfolio sorts using these robustness checks.

[Insert Table 11 around here]

We only report returns of the high minus short $(5-1)$ UP return spread portfolio, after adjusting for the risks captured by the nine-factor model. Panel B reports the results of Fama and MacBeth (1973) regressions (as in column (6) of Panel A in Table 10) of future fund firm alphas in month $t+1$ on $U P$ and different fund characteristics measured in month $t$ using the same stability checks as above. We only report the coefficient estimate for $U P$. Other control variables are included in the regressions, but suppressed in the table. For the ease of comparison, we report the baseline results from column (3) in Panel B of Table 7 and column (6) in Panel A of Table 10. Across all robustness checks, we continue to find a positive and statistically significant effect of $U P$ on future fund firm performance.

\section{Conclusion}

In this paper, we investigate unobserved performance $(U P)$ of hedge funds. We define $U P$ as the risk-adjusted difference between a fund firm's reported return and the hypothetical portfolio returns derived from its disclosed long equity holdings. We show that $U P$ is not a random attribute of a fund firm, but is strongly associated with measures of managerial incentives, fund discretion, and manager skill. We also detect that intraquarter trading of equities, put option strategies, engagement in short-selling, and confidential trading drive $U P$ and are responsible for superior performance of these hedge funds.

We find that $U P$ is able to predict future performance of hedge funds very well. Results from univariate analysis reveal that fund firms with high UP outperform fund firms 
with low $U P$ by roughly $6 \%$ per annum. This spread is stable when we control for a wide array of hedge fund risk factors, and when we control for fund characteristics in multivariate regressions. Interestingly, $U P$ predicts future fund firm performance better that past fund firm performance or past performance derived from long equity positions. Collectively, our study uncovers a new measure of managerial skill in hedge funds by combining returns-based and holdings-based performance measures. Such a measure can help investors better predict future fund performance and understand the sources behind such predictability. 


\section{Appendix}

\section{Figure A.1: Venn Diagram of the Union Hedge Fund Database}

The Union Hedge Fund Database contains a sample of 25,732 hedge funds created by merging four commercial databases: Eureka, HFR, Morningstar, and Lipper TASS. This figure shows the percentage of funds covered by each database individually and by all possible combinations of multiple databases.

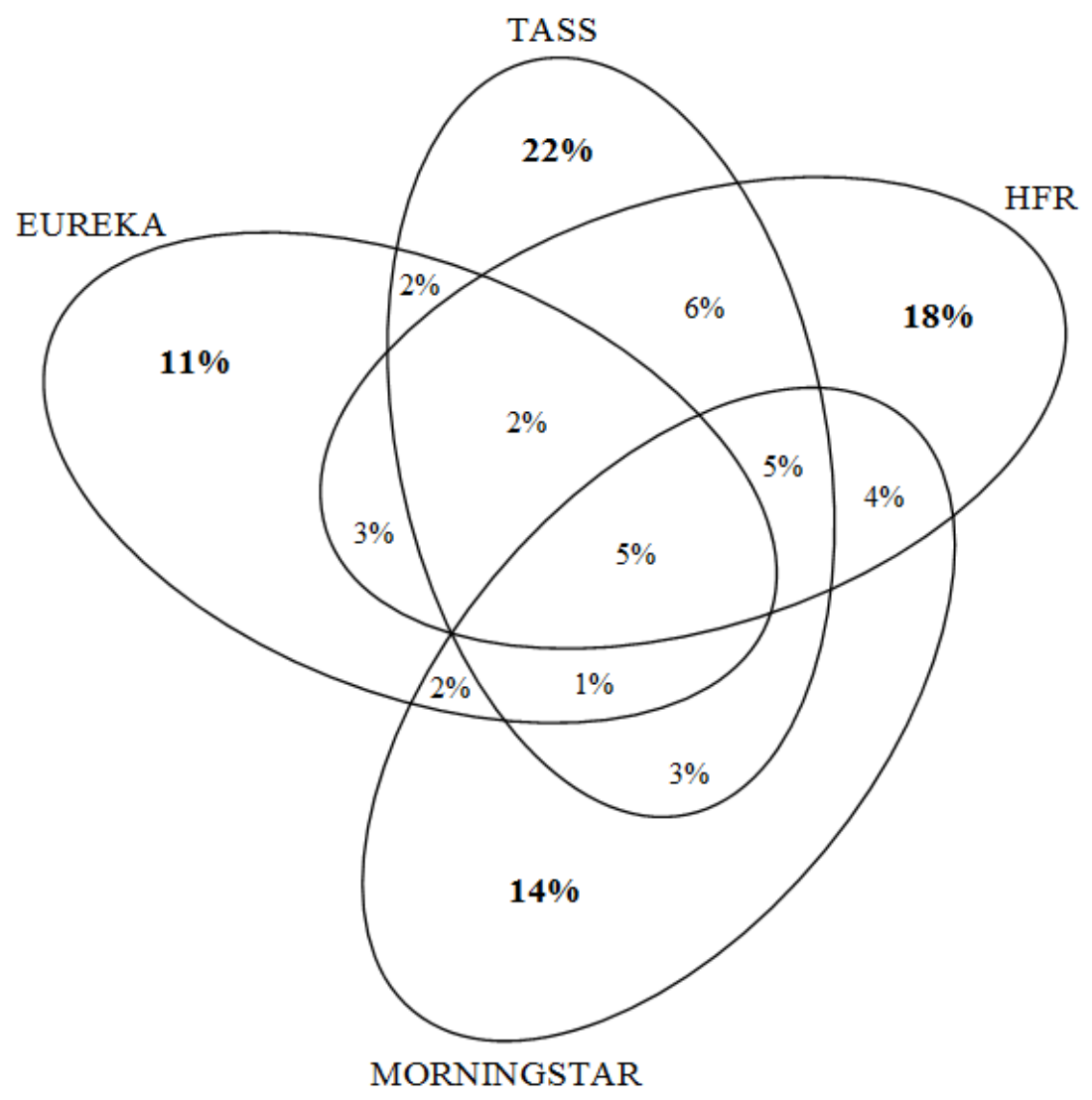




\section{Table A.1: Definitions and Data Sources of Main Variables}

This table briefly defines the main variables used in the empirical analysis. The data sources are; (i) UNION: Union Hedge Fund Database constructed from combining the Eurekahedge, HFR, Morningstar, and Lipper TASS databases, (ii) KF: Kenneth French Data Library, (iii) THOMSON: 13F Thomson Reuter Ownership Database, (iv) DH: David A. Hsieh's webpage, (v) FRS: Data library of the Federal Reserve System, (vi) FED: Data library of the Federal Reserve Bank of St. Louis. (vii) Datastream. EST indicates that the variable is estimated or computed based on original variables from the respective data sources.

\section{Panel A: Unobserved Performance, Returns, and Fund Characteristics}

\begin{tabular}{|c|c|c|}
\hline Variable Name & Description & Source \\
\hline Fund Return & $\begin{array}{l}\text { Monthly excess return of a hedge fund firm, computed as the AUM- } \\
\text { weighted excess return over all funds within a fund firm. As risk-free } \\
\text { rate, the 1-month T-Bill rate is used. }\end{array}$ & $\begin{array}{l}\text { UNION, KF, } \\
\text { EST }\end{array}$ \\
\hline Equity PF Return & $\begin{array}{l}\text { Value-weighted excess return of a fund firm's disclosed equity } \\
\text { holdings including transaction costs as detailed in Section 2.1. As } \\
\text { risk-free rate, the 1-month T-Bill rate is used. }\end{array}$ & $\begin{array}{l}\text { THOMSON, } \\
\text { KF, EST }\end{array}$ \\
\hline$U R C$ & $\begin{array}{l}\text { Unobserved return gap, computed as the difference between a fund } \\
\text { firm's fund return and the equity portfolio return as detailed in } \\
\text { Section 2.2. }\end{array}$ & $\begin{array}{l}\text { UNION, } \\
\text { THOMSON, } \\
\text { EST }\end{array}$ \\
\hline Fund Performance & $\begin{array}{l}\text { Risk-adjusted alpha of a fund firm's reported return series based on a } \\
\text { nine-factor asset pricing model estimated over a time-period of } 36 \\
\text { months. }\end{array}$ & $\begin{array}{l}\text { UNION, KF, } \\
\text { DH, EST }\end{array}$ \\
\hline $\begin{array}{l}\text { Equity PF } \\
\text { Performance }\end{array}$ & $\begin{array}{l}\text { Risk-adjusted alpha of a fund firm's equity portfolio return series } \\
\text { based on a nine-factor asset pricing model estimated over a time- } \\
\text { period of } 36 \text { months. }\end{array}$ & $\begin{array}{l}\text { THOMSON, } \\
\text { KF, DH, EST }\end{array}$ \\
\hline$U P$ & $\begin{array}{l}\text { Unobserved performance, computed as the difference between a fund } \\
\text { firm's fund performance and equity portfolio performance as detailed } \\
\text { in Section } 2.2 \text {. }\end{array}$ & $\begin{array}{l}\text { UNION, } \\
\text { THOMSON } \\
\text { KF, DH, EST }\end{array}$ \\
\hline Size & $\begin{array}{l}\text { Natural logarithm of the hedge fund firm's asset under management } \\
\text { (in \$ million). }\end{array}$ & UNION \\
\hline Age & The age of a hedge fund firm since its inception (in months). & UNION \\
\hline Standard Deviation & $\begin{array}{l}\text { Standard Deviation of a hedge fund firm's reported returns over the } \\
\text { past } 36 \text { months. }\end{array}$ & UNION, EST \\
\hline Delta & $\begin{array}{c}\text { Hedge fund manager's delta computed as the expected dollar change } \\
\text { in the manager's compensation for a } 1 \% \text { change in the fund's net } \\
\text { asset value (in } \$ 100 \text { thousands). Delta per hedge fund firm is } \\
\text { computed as the AUM-weighted delta over all funds within a fund } \\
\text { firm. }\end{array}$ & $\begin{array}{l}\text { Agarwal, } \\
\text { Daniel, and } \\
\text { Naik (2009) }\end{array}$ \\
\hline Management Fee & $\begin{array}{l}\text { The annual hedge fund management fee (in percentage). Computed } \\
\text { as the AUM-weighted management fee over all funds within a fund } \\
\text { firm. }\end{array}$ & UNION \\
\hline Incentive Fee & $\begin{array}{l}\text { The annual hedge fund incentive fee (in percentage). Computed as } \\
\text { the AUM-weighted incentive fee over all funds within a fund firm. }\end{array}$ & UNION \\
\hline
\end{tabular}




\begin{tabular}{|c|c|c|}
\hline & Hedge fund's minimum investment amount (in $\$ 100$ thousands). & \\
\hline Min Investment & $\begin{array}{l}\text { Computed as the AUM-weighted minimum investment over all funds } \\
\text { within a fund firm. }\end{array}$ & UNION \\
\hline Lockup Period & $\begin{array}{c}\text { The lockup period of a hedge fund, defined as the minimum amount of } \\
\text { time that an investor is required to keep his money invested in the fund } \\
\text { (in years). Computed as the AUM-weighted lockup period over all funds } \\
\text { within a fund firm. }\end{array}$ & UNION \\
\hline Restriction Period & $\begin{array}{l}\text { The restriction period of a hedge fund, computed as the sum of its notice } \\
\text { period and redemption period (in years). Computed as the AUM- } \\
\text { weighted restriction period over all funds within a fund firm. }\end{array}$ & UNION \\
\hline Offshore & $\begin{array}{l}\text { Indicator variable that takes the value of one if the largest hedge fund in } \\
\text { the fund firm is located outside of the USA and zero otherwise. }\end{array}$ & UNION \\
\hline Leverage & $\begin{array}{l}\text { Indicator variable that takes the value of one if the largest hedge fund in } \\
\text { the fund firm uses leverage and zero otherwise. }\end{array}$ & UNION \\
\hline HWM & $\begin{array}{l}\text { Indicator variable that takes the value of one if the largest hedge fund in } \\
\text { the fund firm uses a high-watermark and zero otherwise. }\end{array}$ & UNION \\
\hline Hurdle Rate & $\begin{array}{l}\text { Indicator variable that takes the value of one if the largest hedge fund in } \\
\text { the fund firm uses a hurdle rate and zero otherwise. }\end{array}$ & UNION \\
\hline $\mathrm{R}^{2}$ & $\begin{array}{c}\text { Titman and Tiu (2011)'s R2 measure of a fund firm to the extendend } \\
\text { Fung and Hiseh (2004) nine-factor model estimated based on the past } 36 \\
\text { months. }\end{array}$ & UNION, EST \\
\hline$S D I$ & $\begin{array}{l}\text { Sun, Wang, and Zheng (2012)'s strategy distinctiveness index computed } \\
\text { as one minus the correlation between a fund firm's return and the } \\
\text { average return of the style group estimated based on the past } 36 \text { months. }\end{array}$ & UNION, EST \\
\hline
\end{tabular}




\section{Panel B: Hedge Fund Risk Factors}

\begin{tabular}{|c|c|c|}
\hline Variable Name & Description & Source \\
\hline$S \& P$ & The S\&P 500 index monthly total return. & DH \\
\hline$S C M L C$ & $\begin{array}{l}\text { The size spread factor, computed as the difference between the } \\
\text { Russell } 2000 \text { index monthly return and the S\&P } 500 \text { monthly } \\
\text { return. }\end{array}$ & DH \\
\hline BDIORET & $\begin{array}{l}\text { The bond market factor, computed as the monthly change in the } \\
10 \text {-year treasury maturity yield. }\end{array}$ & FRS \\
\hline BAAMTSY & $\begin{array}{c}\text { The credit spread factor, computed as the monthly change in the } \\
\text { Moody's Baa yield less } 10 \text {-year treasury constant maturity } \\
\text { yield. }\end{array}$ & FRS \\
\hline PTFSBD & Trend-following risk factor in bonds (monthly returns). & DH \\
\hline PTFSFX & Trend-following risk factor in currencies (monthly returns). & DH \\
\hline PTFSCOM & Trend-following risk factor in commodities (monthly returns). & DH \\
\hline$H M L$ & $\begin{array}{c}\text { Fama and French (1993) high-minus-low value factor (monthly } \\
\text { returns). }\end{array}$ & $\mathrm{KF}$ \\
\hline$U M D$ & $\begin{array}{c}\begin{array}{c}\text { Carhart (1997) up-minus-down momentum factor (monthly } \\
\text { returns). }\end{array} \\
\end{array}$ & $\mathrm{KF}$ \\
\hline PS Liqui & $\begin{array}{l}\text { The Pástor and Stambaugh (2003) traded liquidity risk factor } \\
\text { (monthly returns). }\end{array}$ & $\begin{array}{c}\text { Pástor and } \\
\text { Stambaugh (2003) }\end{array}$ \\
\hline$B A B$ & $\begin{array}{l}\text { The Frazzini and Pedersen (2014) betting-against-beta factor } \\
\text { (monthly returns). }\end{array}$ & $\begin{array}{l}\text { Frazzini and } \\
\text { Pedersen (2014) }\end{array}$ \\
\hline Return Macro & $\begin{array}{l}\text { The Bali, Brown, and Caglayan (2014) macroeconomic } \\
\text { uncertainty factor (monthly returns). }\end{array}$ & $\begin{array}{l}\text { Bali, Brown, and } \\
\text { Caglayan (2014) }\end{array}$ \\
\hline Return Corr & $\begin{array}{l}\text { The Buraschi, Kosowski, and Trojani (2014) correlation risk } \\
\text { factor (monthly returns). }\end{array}$ & $\begin{array}{l}\text { Buraschi, } \\
\text { Kosowski, and } \\
\text { Trojani }(2014)\end{array}$ \\
\hline Return VIX & Monthly relative changes in the CBOE volatility index (VIX). & FED \\
\hline Return $R I X$ & The Gao, Gao, and Song (2018) RIX factor (monthly returns). & $\begin{array}{l}\text { Gao, Gao, and } \\
\text { Song (2018) }\end{array}$ \\
\hline Return Tailrisk & $\begin{array}{c}\text { The Agarwal, Ruenzi, and Weigert (2017) tail risk factor } \\
\text { (monthly returns). }\end{array}$ & $\begin{array}{l}\text { Agarwal, Ruenzi, } \\
\text { and Weigert (2017) }\end{array}$ \\
\hline Return EM Equity & The MSCI Emerging Market index monthly total return. & Datastream \\
\hline Return Bond & $\begin{array}{l}\text { The monthly return of the Barclays US Aggregate Bond index. } \\
\text { The monthly return of the S\&P GSCI commodity index }\end{array}$ & Datastream \\
\hline Return Commodity & The monthly return of the S\&P GSCI commodity index. & Datastream \\
\hline
\end{tabular}




\section{References}

Alexander, G.J., Cici, G., Gibson, S., 2007. Does motivation matter when assessing trade performance? An analysis of mutual funds. Review of Financial Studies 20, 125-150.

Agarwal, V., Arisoy, Y.E., Naik, N.Y., 2017. Volatility of aggregate volatility and hedge fund returns. Journal of Financial Economics 125, 491-510.

Agarwal, V., Bakshi, G., Huij, J., 2009. Do higher-moment equity risks explain hedge fund returns? Unpublished working paper. Erasmus University, Georgia State University, and University of Maryland.

Agarwal, V., Daniel, N.D., Naik, N.Y., 2009. Role of managerial incentives and discretion in hedge fund performance. Journal of Finance 64, 2221-2256.

Agarwal, V., Fos, V., Jiang, W., 2013. Inferring reporting-related biases in hedge fund databases from hedge fund equity holdings. Management Science 59, 1271-1289.

Agarwal, V., Jiang, W., Tang, Y., Yang, B., 2013. Uncovering hedge fund skill from the portfolios they hide. Journal of Finance 68, 739-783.

Agarwal, V., Mullally, K.A., Naik, N.Y., 2015. The economics and finance of hedge funds: A review of the academic literature. Foundations and Trends in Finance 10, 1-111.

Agarwal, V., Naik, N.Y., 2004. Risks and portfolio decisions involving hedge funds. Review of Financial Studies 17, 63-98.

Agarwal, V., Ruenzi, S., Weigert, F., 2017. Tail risk in hedge funds: A unique view from portfolio holdings. Journal of Financial Economics 125, 610-636.

Aggarwal, R.K., Jorion, P., 2010. The performance of emerging hedge funds and managers. Journal of Financial Economics 96, 238-256.

Aragon, G.O., 2007. Share restrictions and asset pricing: Evidence from the hedge fund industry. Journal of Financial Economics 83, 33-58.

Aragon G.O., Hertzel, M., Shi, Z., 2013. Why do hedge funds avoid disclosure? Evidence from confidential 13F filings. Journal of Financial and Quantitative Analysis 48, 14991518.

Aragon, G.O., Martin, J.S., 2012. A unique view of hedge fund derivatives usage: Safeguard or speculation? Journal of Financial Economics 105, 436-456.

Aragon, G.O., Martin, J.S., Shi Z., 2018. Who benefits in a crisis? Evidence from hedge fund stock and option holdings. Journal of Financial Economics, forthcoming. 
Amihud, Y., 2002. Illiquidity and stock returns: cross-section and time-series effects. Journal of Financial Markets 5, 31-56.

Baker, M., Wurgler, J., 2006. Investor sentiment and the cross-section of stock returns. Journal of Finance 61, 1645-1680.

Bali, T.G., Brown, S.J., Caglayan, M.O., 2014. Macroeconomic risk and hedge fund returns. Journal of Financial Economics 114, 1-19.

Barber, B.M., Odean, T., 2000. Trading is hazardous to your wealth: The common stock investment performance of individual investors. Journal of Finance 55, 773-806.

Bennett, J.A., Sias, R.W., Starks, L, 2003. Greener pastures and the impact of dynamic institutional preferences. Review of Financial Studies 16, 1203-1238.

Von Beschwitz, B., Lunghi, S., Schmidt, D., 2017. Limits of arbitrage under the microscope: evidence from detailed hedge fund transaction data. Unpublished working paper. Board of Governors of the Federal Reserve System, Inalytics Limited, and HEC Paris.

Bondarenko, O., 2004. Market price of variance risk and performance of hedge funds. Unpublished working paper. University of Illinois.

Buraschi, A., Kosowski, R., Trojani, F., 2014. When there is no place to hide: correlation risk and the cross-section of hedge fund returns. Review of Financial Studies 27, 581-616.

Cao, C., Goldie, B.A., Liang, B., Petrasek, L., 2018. What is the nature of hedge fund manager skills? Evidence from the risk-arbitrage strategy. Journal of Financial and Quantitative Analysis 51, 929-957.

Cai, F., Zheng, L, 2004. Institutional trading and stock returns. Finance Research Letters 1, $178-189$.

Chen, H-L., Jegadessh, N., Wermers, R., 2000. The value of active mutual fund management: an examination of the stockholdings and trades of fund managers. Journal of Financial and Quantitative Analysis 35, 343-368.

Fama, E.F., MacBeth, J.D., 1973. Risk, return, and equilibrium: empirical tests. Journal of Political Economy 81, 607-636.

Fung, W., Hsieh, D.A., 2004. Hedge fund benchmarks: A risk-based approach. Financial Analysts Journal 60, 65-80.

Frazzini, A., Pedersen, L.H., 2014. Betting against beta. Journal of Financial Economics 111, $1-25$.

Gao, G.P., Gao, P, Song, Z., 2018. Do hedge funds exploit rare disaster concerns? Review of Financial Studies 31, 2650-2692. 
Getmansky, M., Lo, A.W., Makarov, I., 2004. An econometric model of serial correlation and illiquidity in hedge fund returns. Journal of Financial Economics 74, 319-352.

Griffin, J.M., Xu, J., 2009. How smart are the smart guys? A unique view from hedge fund stock holdings. Review of Financial Studies 22, 2331-2370.

Hodder, J.E., Jackwerth, J.C., Kolokolova, O., 2014. Recovering delisting returns of hedge funds. Journal of Financial and Quantitative Analysis 49, 797-815.

Jame, R., 2018. Liquidity provision and the cross-section of hedge fund returns. Management Science 64, 3288-3312.

Jank, S., Smajlbegovic, E., 2017. Dissecting short-sale performance: Evidence from large position disclosures. Unpublished Working Paper. Deutsche Bundesbank and Erasmus University Rotterdam.

Joenväärä, J., Kauppila, M., Tolonen, P., 2018. Information content of hedge fund equity option holdings. Unpublished Working Paper. University of Oulu.

Jones, C.M., Reed, A.V., Waller, W., 2016. Revealing shorts: an examination of large short position disclosures. Review of Financial Studies 29, 3278-3320.

Jurek, J.W., Stafford, E., 2015. The cost of capital for alternative investments. Journal of Finance 70, 2185-2226.

Kacperczyk, M., Sialm, C., Zheng, L., 2005. On the industry concentration of actively managed equity mutual funds. Journal of Finance 60, 1983-2011.

Kacperczyk, M., Sialm, C., Zheng, L., 2008. Unobserved actions of mutual funds. Review of Financial Studies 21, 2379-2416.

Kosowski, R., Naik, N.Y., Teo, M., 2007. Do hedge funds deliver alpha? A Bayesian and bootstrap analysis. Journal of Financial Economics 84, 229-264 .

Newey, W.K., West, K.D., 1987. A simple, positive semi-definite, heteroskedasticity and autocorrelation consistent covariance matrix. Econometrica 55, 703-708.

Pástor, L., Stambaugh, R., 2003. Liquidity risk and expected stock returns. Journal of Political Economy 111, 642-685.

Pástor, L., Stambaugh, R., Taylor, L.A., 2017. Do funds make more when they trade more? Journal of Finance 72, 1483-1528.

Puckett, A., Yan, X., 2011. The interim trading skills of institutional investors. Journal of Finance 66, 601-633.

Rapach, D.E., Ringgenberg, M.C., Zhou, G., 2016. Short interest and aggregate stock returns. Journal of Financial Economics 121, 46-65. 
Sadka, R., 2010. Liquidity risk and the cross-section of hedge fund returns. Journal of Financial Economics 98, 54-71.

Shanken, J., 1992. On the estimation of beta-pricing models. Review of Financial Studies 5, $1-33$.

Sun, Z., Wang, A., Zheng, L., 2012. The road less traveled: Strategy distinctiveness and hedge fund performance. Review of Financial Studies 25, 96-143.

Teo, M., 2011. The liquidity risk of liquid hedge funds. Journal of Financial Economics 100, $24-44$.

Titman, S., Tiu, C., 2011. Do the best hedge funds hedge? Review of Financial Studies 24, $123-168$.

Wermers, R., 2000. Mutual fund performance: an empirical decomposition into stock-picking talent, style, transaction costs, and expenses. Journal of Finance 55, 1655-1703.

Yan, X., Zhang, Z., 2009. Institutional investors and equity returns: are short-term institutions better informed? Review of Financial Studies 22, 893-924. 


\section{Figure 1: Aggregate Reported Returns, Aggregate Equity Portfolio Returns, and Aggregate $U R C$}

Panel A displays the evolution of the aggregate reported returns and aggregate equity portfolio returns. Panel B displays the evolution of the aggregate unobserved return component (URC). Our sample covers hedge fund firms from the Union Hedge Fund Database constructed from combining the Eurekahedge, HFR, Morningstar, and Lipper TASS databases who report 13F long equity holdings to the SEC. The sample period is from January 1994 to December 2012.

\section{Panel A: Aggregate Reported Returns and Equity Portfolio Returns}

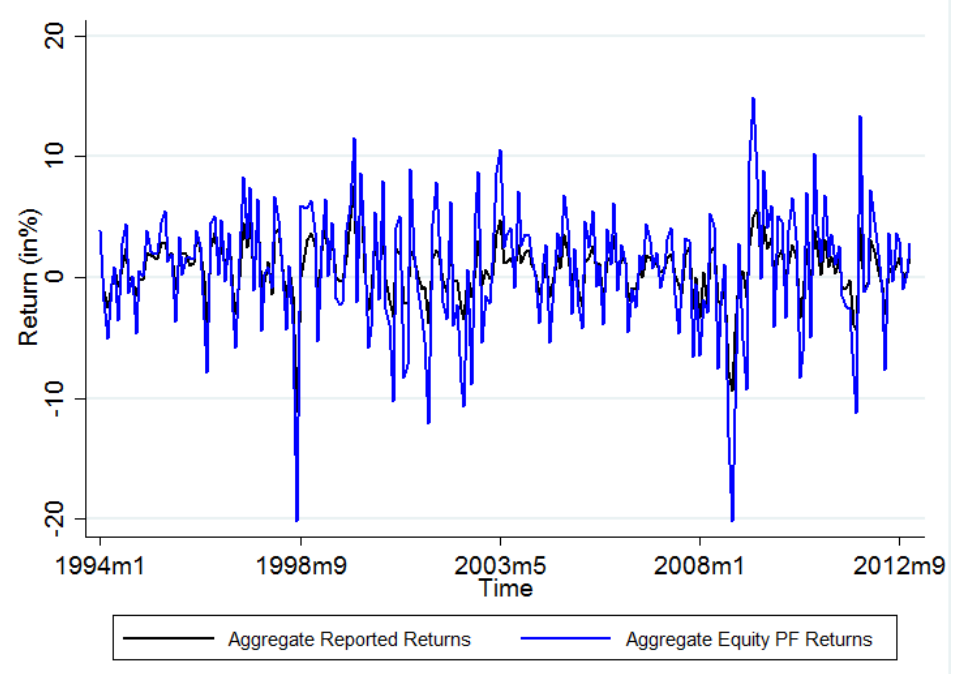

Panel B: Aggregate Unobserved Return Component (URC)

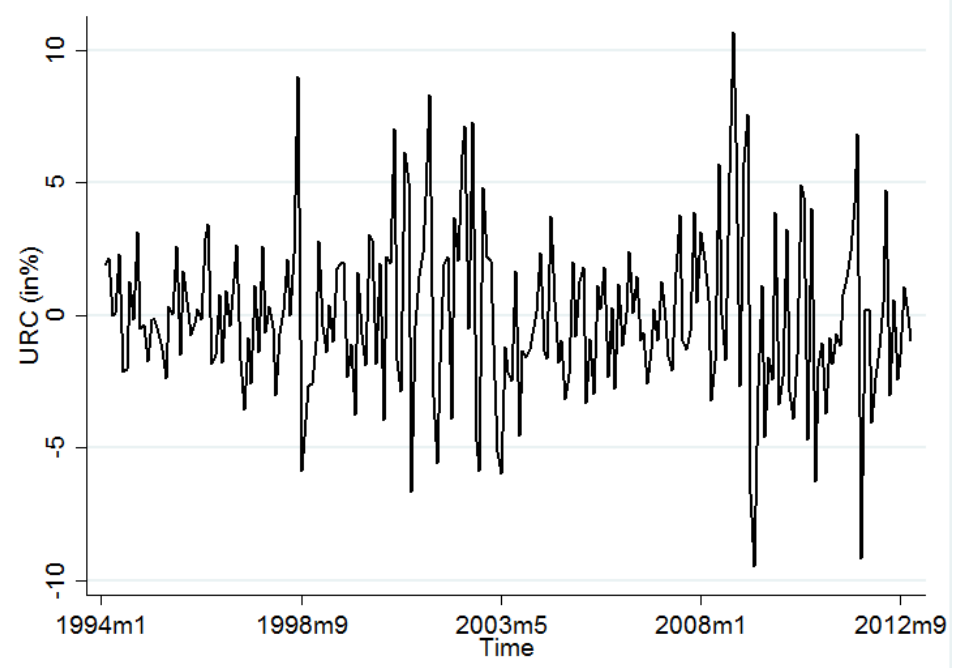




\section{Figure 2: Cumulative Returns}

This figure displays the temporal variation of the cumulative monthly returns for three hypothetical long-short investment strategies: (i) a trading strategy based on Fund Performance, (ii) a trading strategy based on Equity PF Performance, and (iii) a trading strategy based on UP. For each strategy we go long the quintile of hedge funds with the highest realizations of the respective sorting criteria and go short the quintile with the lowest realizations and apply monthly rebalancing without accounting of trading costs. We assume an investment of $\$ 100$ at the beginning of 1997 (i.e., at the end of the first estimation of the performance metrics based on a horizon of 36 months). Our sample covers hedge fund firms from the Union Hedge Fund Database constructed from combining the Eurekahedge, HFR, Morningstar, and Lipper TASS databases who report 13F long equity holdings to the SEC. The sample period is from January 1994 to December 2012.

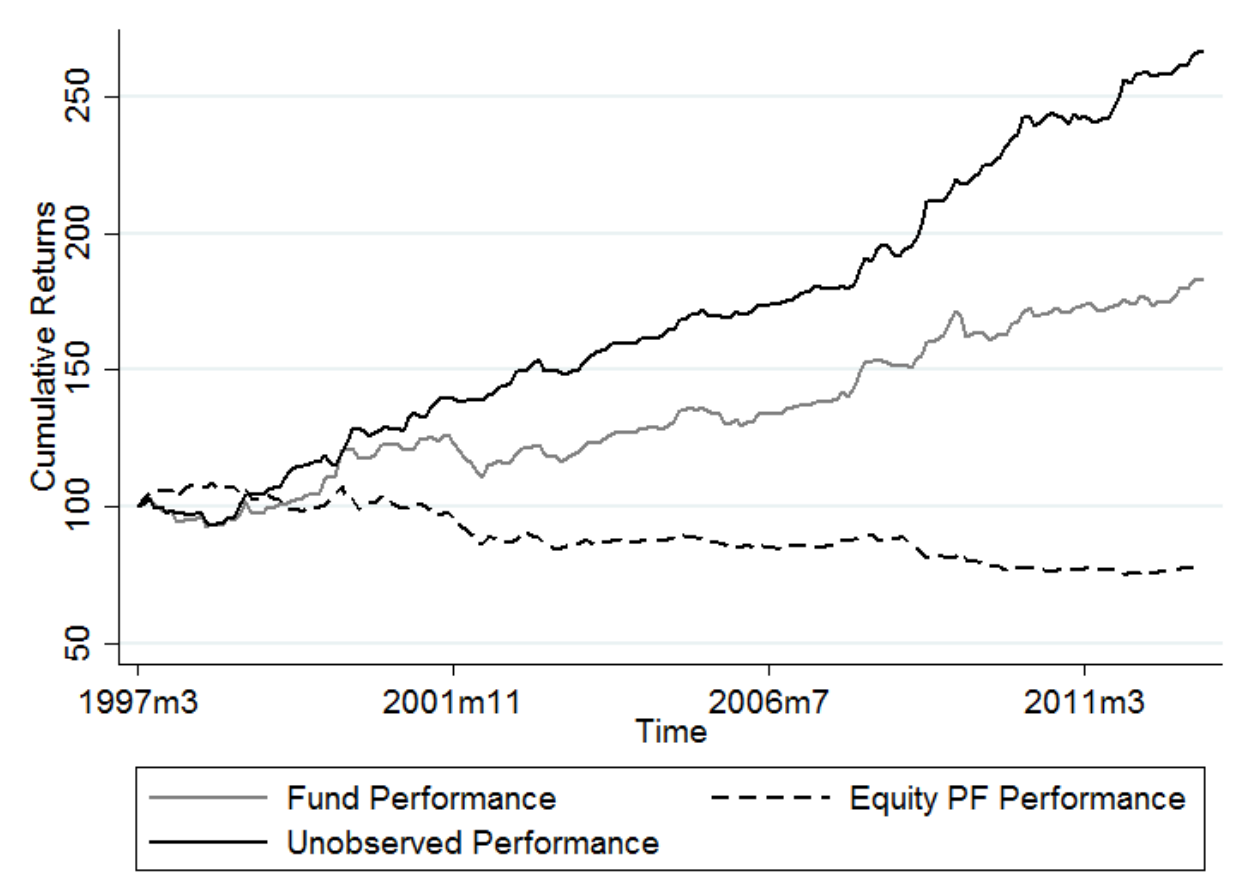




\section{Table 1: Descriptive Statistics}

Panel A of this table provides descriptive statistics for the main variables in our empirical study that include the monthly excess fund firm returns (over the risk-free rate), the fund firm's portfolio excess return, the unobserved return component $(U R C)$, and different fund characteristics. Panel B reports the results of a time-series regression of aggregate reported returns, aggregate equity portfolio returns, and the aggregate $U R C$ on the risk factors of Fung and Hsieh (2004)'s seven-factor model (i.e., $S \& P$, SCMLC, BDIORET, BAAMTSY, PTFSBD, PTFSFX, and, PTFSCOM) augmented by the Fama and French (1993) book-to-market factor (HML) and the Carhart (1997) momentum factor (UMD). Panel C displays descriptive statistics for fund performance, equity portfolio performance, and the unobserved performance $(U P)$ of hedge fund firms. Panel D reports correlations between $U P$, fund performance, equity portfolio performance, and fund characteristics. Descriptive statistics are calculated over all hedge fund firms and months in our sample period. Our sample is the intersection of hedge fund firms from the Union Hedge Fund Database (constructed from combining the Eurekahedge, HFR, Morningstar, and Lipper TASS databases) and firms that report 13F long equity holdings to the SEC. The sample period is from January 1994 to December 2012.

\section{Panel A: Returns and Fund Characteristics}

\begin{tabular}{llllll}
\hline Variable & Mean & $\mathbf{2 5 \%}$ & Median & $\mathbf{7 5 \%}$ & StdDev \\
\hline $\begin{array}{l}\text { Fund Firm Return } \\
\text { Equity Portfolio Return } \\
\text { (including transaction }\end{array}$ & $0.49 \%$ & $-1.09 \%$ & $0.55 \%$ & $2.17 \%$ & 4.43 \\
costs) & $0.55 \%$ & $-2.78 \%$ & $0.93 \%$ & $4.16 \%$ & 6.90 \\
Unobserved Return & & & & & \\
Component (URC) & $-0.06 \%$ & $-2.64 \%$ & $-0.21 \%$ & $2.35 \%$ & 5.68 \\
Size & 5.41 & 4.41 & 5.56 & 6.64 & 1.77 \\
Age (in months) & 96.37 & 45.00 & 83.00 & 134.00 & 66.62 \\
Standard Deviation & 3.54 & 1.76 & 2.82 & 4.53 & 2.60 \\
Delta (in \$100 thousands) & 5.11 & 0.49 & 1.93 & 6.70 & 6.86 \\
Management Fee (in \%) & 1.41 & 1.00 & 1.46 & 1.62 & 0.51 \\
Incentive Fee (in \%) & 18.76 & 20.00 & 20.0 & 20.00 & 4.36 \\
Min Investment (in \$100 & 25.31 & 5.00 & 10.00 & 18.31 & 199.63 \\
thousands) & & 0.00 & 0.23 & 1.00 & 0.56 \\
Lockup Period (in years) & 0.47 & 0.22 & 0.33 & 0.48 & 0.28 \\
Restriction Period (in & 0.41 & 0.00 & 0.00 & 1.00 & 0.49 \\
years) & 0.42 & 0.00 & 1.00 & 1.00 & 0.46 \\
Offshore & 0.68 & 1.00 & 1.00 & 1.00 & 0.35 \\
Leverage & 0.85 & 0.46 & 0.00 & 1.00 & 0.47 \\
HWM & 0.32 & 0.63 & 0.76 & 0.20 \\
Hurdle Rate & 0.61 & 0.22 & 0.35 & 0.61 & 0.27 \\
R2 & & & & \\
SDI & & & & & \\
\hline
\end{tabular}


Panel B: Aggregate $U R C$ and Risk Factors

\begin{tabular}{cccc}
\hline & $(1)$ & $(2)$ & $(3)$ \\
& Aggregate Reported & $\begin{array}{c}\text { Aggregate Equity } \\
\text { Return }\end{array}$ & Aggregate URC \\
\hline S\&P & $0.394 * * *$ & $1.022^{* * *}$ & $-0.626^{* * *}$ \\
& $(13.50)$ & $(60.47)$ & $(-23.06)$ \\
SCMLC & $0.152^{* * *}$ & $0.307 * * *$ & $-0.144 * * *$ \\
& $(4.69)$ & $(8.97)$ & $(-6.99)$ \\
BD10RET & -0.00538 & -0.0211 & 0.0192 \\
& $(-0.12)$ & $(-0.57)$ & $(0.91)$ \\
BAAMTSY & $0.251^{* * *}$ & $0.137 * * *$ & $0.112^{* * *}$ \\
& $(5.34)$ & $(2.63)$ & $(7.49)$ \\
PTFSBD & $-0.00928^{*}$ & -0.00260 & -0.00587 \\
& $(-1.77)$ & $(-0.62)$ & $(-1.32)$ \\
PTFSFX & $0.00724 * *$ & 0.00468 & 0.00252 \\
& $(2.55)$ & $(1.54)$ & $(1.03)$ \\
PTFSCOM & -0.00121 & -0.00496 & 0.00293 \\
& $(-0.19)$ & $(-0.72)$ & $(0.62)$ \\
HML & -0.0159 & 0.0668 & $-0.0869 * * *$ \\
& $(-0.31)$ & $(1.09)$ & $(-5.89)$ \\
UMD & $0.0416 * *$ & $-0.0332 * *$ & $0.0736 * * *$ \\
Constant & $(2.38)$ & $(-2.03)$ & $(6.63)$ \\
& $0.316 * * *$ & 0.0318 & $0.291 * * *$ \\
Observations & $(3.31)$ & $(0.36)$ & $(3.76)$ \\
Adjusted $R^{2}$ & 227 & 227 & 227 \\
& 0.827 & 0.966 & 0.944 \\
\hline
\end{tabular}

\section{Panel C: Fund Performance, Equity PF Performance and Unobserved Performance (UP)}

\begin{tabular}{lllllll}
\hline Variable & $\begin{array}{l}\text { Number of } \\
\text { Fund Firms }\end{array}$ & Mean & $\mathbf{2 5 \%}$ & Median & $\mathbf{7 5 \%}$ & StdDev \\
\hline Fund Performance & 668 & $0.27 \%$ & $-0.81 \%$ & $0.25 \%$ & $1.33 \%$ & 2.35 \\
Equity PF Performance & 668 & $0.06 \%$ & $-1.16 \%$ & $0.02 \%$ & $1.29 \%$ & 2.88 \\
Unobserved & 668 & $0.22 \%$ & $-1.22 \%$ & $0.17 \%$ & $1.62 \%$ & 3.04 \\
Performance (UP) & & & & & & \\
\hline & Number of & Mean & $\mathbf{2 5 \%}$ & Median & $\mathbf{7 5 \%}$ & StdDev \\
\hline $\boldsymbol{U P}$ for HF Strategy & Fund Firms & & & & & \\
\hline Emerging Markets & 14 & $0.23 \%$ & $-1.58 \%$ & $0.15 \%$ & $2.04 \%$ & 3.36 \\
Event Driven & 96 & $0.16 \%$ & $-1.29 \%$ & $0.10 \%$ & $1.54 \%$ & 3.04 \\
Global Macro & 36 & $0.13 \%$ & $-1.73 \%$ & $0.21 \%$ & $2.11 \%$ & 3.59 \\
Equity Long-Short & 333 & $0.21 \%$ & $-1.19 \%$ & $0.14 \%$ & $1.54 \%$ & 2.84 \\
Equity Market Neutral & 33 & $0.20 \%$ & $-0.88 \%$ & $0.19 \%$ & $1.39 \%$ & 2.72 \\
Multi-Strategy & 61 & $0.27 \%$ & $-1.06 \%$ & $0.24 \%$ & $1.61 \%$ & 2.87 \\
Relative Value & 68 & $0.25 \%$ & $-1.50 \%$ & $0.24 \%$ & $1.98 \%$ & 3.96 \\
Sector & 17 & $0.33 \%$ & $-1.23 \%$ & $0.21 \%$ & $1.73 \%$ & 3.03 \\
Others & 10 & $0.28 \%$ & $-1.19 \%$ & $0.24 \%$ & $1.98 \%$ & 3.15 \\
\hline
\end{tabular}


Panel D: Correlations

\begin{tabular}{|c|c|c|c|c|c|c|c|c|c|c|c|c|c|c|c|c|c|c|}
\hline & UP & $\begin{array}{l}\text { Fund } \\
\text { Performance }\end{array}$ & $\begin{array}{l}\text { Equity PF } \\
\text { Performance }\end{array}$ & Size & Age & $\begin{array}{l}\text { Standard } \\
\text { Deviation }\end{array}$ & Delta & $\begin{array}{l}\text { Management } \\
\text { Fee }\end{array}$ & $\begin{array}{l}\text { Incentive } \\
\text { Fee }\end{array}$ & $\begin{array}{l}\text { Min } \\
\text { Investment }\end{array}$ & $\begin{array}{l}\text { Lockup } \\
\text { Period }\end{array}$ & $\begin{array}{l}\text { Restriction } \\
\text { Period }\end{array}$ & Offshore & Leverage & HWM & $\begin{array}{l}\text { Hurdle } \\
\text { Rate }\end{array}$ & $\mathrm{R}^{2}$ & SDI \\
\hline UP & +1.00 & & & & & & & & & & & & & & & & & \\
\hline $\begin{array}{l}\text { Fund } \\
\text { Performance }\end{array}$ & +0.44 & +1.00 & & & & & & & & & & & & & & & & \\
\hline $\begin{array}{l}\text { Equity PF } \\
\text { Performance }\end{array}$ & -0.61 & +0.36 & +1.00 & & & & & & & & & & & & & & & \\
\hline Size & -0.02 & -0.00 & +0.01 & +1.00 & & & & & & & & & & & & & & \\
\hline Age & -0.02 & -0.04 & -0.01 & 0.26 & +1.00 & & & & & & & & & & & & & \\
\hline Delta & +0.09 & +0.04 & +0.02 & +0.62 & +0.33 & -0.06 & +1.00 & & & & & & & & & & & \\
\hline Mgmt. Fee & +0.01 & +0.02 & +0.01 & +0.14 & -0.03 & -0.06 & +0.22 & +1.00 & & & & & & & & & & \\
\hline Inc. Fee & +0.02 & +0.01 & +0.01 & +0.03 & -0.08 & -0.01 & +0.15 & +0.28 & +1.00 & & & & & & & & & \\
\hline Min Inv & +0.00 & +0.00 & -0.00 & +0.04 & +0.02 & -0.01 & +0.02 & +0.06 & +0.01 & +1.00 & & & & & & & & \\
\hline Lockup & +0.05 & +0.00 & +0.01 & -0.08 & -0.06 & +0.06 & -0.06 & -0.07 & +0.17 & +0.12 & +1.00 & & & & & & & \\
\hline Restriction & +0.00 & +0.02 & +0.01 & +0.07 & +0.07 & -0.03 & +0.17 & -0.06 & +0.12 & +0.04 & +0.18 & +1.00 & & & & & & \\
\hline Leverage & +0.05 & +0.00 & -0.01 & -0.03 & -0.07 & +0.06 & -0.01 & +0.19 & +0.22 & -0.13 & +0.08 & -0.00 & +0.12 & +1.00 & & & & \\
\hline HWM & -0.00 & +0.00 & +0.00 & -0.00 & -0.09 & -0.04 & +0.05 & +0.00 & +0.40 & +0.02 & +0.15 & +0.18 & -0.02 & +0.19 & +1.00 & & & \\
\hline Hurdle Rate & +0.04 & +0.01 & +0.01 & -0.13 & +0.10 & +0.06 & -0.14 & -0.07 & +0.04 & -0.03 & +0.17 & +0.18 & -0.51 & +0.01 & -0.01 & +1.00 & & \\
\hline $\mathrm{R}^{2}$ & -0.08 & -0.04 & +0.00 & +0.00 & +0.17 & +0.25 & -0.02 & -0.15 & -0.15 & -0.03 & +0.05 & +0.02 & -0.10 & -0.16 & -0.07 & -0.00 & +1.00 & \\
\hline SDI & +0.05 & +0.04 & +0.02 & -0.11 & -0.21 & -0.20 & -0.06 & +0.07 & +0.11 & +0.02 & -0.06 & -0.07 & +0.00 & +0.05 & +0.03 & +0.02 & -0.64 & +1.00 \\
\hline
\end{tabular}




\section{Table 2: Determinants of $U P$}

This table reports the results of Fama and MacBeth (1973) regressions of UP in month $t+1$ on fund characteristics in month $t$. As fund characteristics, we include a fund firm's monthly return, size, age, standard deviation (estimated over the previous 24 months), the delta of the incentive fee contract, a fund firm's management and incentive fee (in \%), minimum investment amount (in \$100 thousands), the length of a fund firm's lockup and restriction period (in years), indicator variables that equal one if the fund is an offshore fund, employs leverage, has a high water mark and a hurdle rate, the $\mathrm{R}^{2}$ measure of Titman and Tiu (2011), and the SDI measure of Sun, Wang, and Zheng (2012). Our sample covers hedge fund firms from the Union Hedge Fund Database constructed from combining the Eurekahedge, HFR, Morningstar, and Lipper TASS databases who report $13 \mathrm{~F}$ long equity holdings to the SEC. The sample period is from January 1994 to December 2012. We use the NeweyWest (1987) adjustment with 36 lags to adjust the standard errors for potential serial correlation. ***, $* *$, and $*$ denote statistical significance at the $1 \%, 5 \%$, and $10 \%$ level, respectively.

\begin{tabular}{|c|c|c|c|c|}
\hline & (1) & (2) & (3) & (4) \\
\hline & UP & UP & UP & UP \\
\hline & $t+1$ & $t+1$ & $t+1$ & $t+1$ \\
\hline Fund Return & $\begin{array}{l}0.0453 * * * \\
(5.26)\end{array}$ & & $\begin{array}{l}0.0498 * * * \\
(5.88)\end{array}$ & $\begin{array}{l}0.0527 * * * \\
(7.02)\end{array}$ \\
\hline Size & $\begin{array}{l}-0.0533 * * \\
(-2.20)\end{array}$ & & $\begin{array}{l}-0.0556^{*} \\
(-1.82)\end{array}$ & $\begin{array}{l}-0.0529 \\
(-1.35)\end{array}$ \\
\hline Age & $\begin{array}{l}-0.000227 \\
(-0.46)\end{array}$ & & $\begin{array}{l}-0.000485 \\
(-0.58)\end{array}$ & $\begin{array}{l}-0.000868 \\
(-1.48)\end{array}$ \\
\hline Standard Deviation & $\begin{array}{l}-0.0118 \\
(-0.75)\end{array}$ & & $\begin{array}{l}-0.0125 \\
(-0.76)\end{array}$ & $\begin{array}{l}0.00585 \\
(0.32)\end{array}$ \\
\hline Delta & $\begin{array}{l}0.00643 * * \\
(2.52)\end{array}$ & & $\begin{array}{l}0.00660 * \\
(1.74)\end{array}$ & $\begin{array}{l}0.00379 \\
(1.44)\end{array}$ \\
\hline Management Fee & & $\begin{array}{l}0.0777^{*} \\
(1.69)\end{array}$ & $\begin{array}{l}0.106^{*} \\
(1.82)\end{array}$ & $\begin{array}{l}0.0820 \\
(1.52)\end{array}$ \\
\hline Incentive Fee & & $\begin{array}{l}-0.00368 \\
(-0.45)\end{array}$ & $\begin{array}{l}-0.0105 \\
(-1.12)\end{array}$ & $\begin{array}{l}-0.0100 \\
(-1.25)\end{array}$ \\
\hline Minimum Investment & & $\begin{array}{l}-0.00319 \\
(-1.28)\end{array}$ & $\begin{array}{l}-0.00268 \\
(-1.11)\end{array}$ & $\begin{array}{l}-0.00195 \\
(-0.89)\end{array}$ \\
\hline Lockup Period & & $\begin{array}{l}0.144 \\
(1.15)\end{array}$ & $\begin{array}{l}0.132 * \\
(1.86)\end{array}$ & $\begin{array}{l}0.144 * * \\
(2.43)\end{array}$ \\
\hline Restriction Period & & $\begin{array}{l}0.119 * \\
(1.66)\end{array}$ & $\begin{array}{l}0.0550 \\
(0.53)\end{array}$ & $\begin{array}{l}0.0666 \\
(0.90)\end{array}$ \\
\hline Offshore & & $\begin{array}{l}0.149 * * \\
(2.18)\end{array}$ & $\begin{array}{l}0.116 \\
(1.16)\end{array}$ & $\begin{array}{l}0.122 * \\
(1.70)\end{array}$ \\
\hline Leverage & & $\begin{array}{l}0.0565 \\
(0.62)\end{array}$ & $\begin{array}{l}0.0923 * \\
(1.82)\end{array}$ & $\begin{array}{l}0.0997 * * \\
(2.12)\end{array}$ \\
\hline High Watermark & & $\begin{array}{l}-0.00207 \\
(-0.02)\end{array}$ & $\begin{array}{l}0.0431 \\
(0.33)\end{array}$ & $\begin{array}{l}-0.0145 \\
(-0.13)\end{array}$ \\
\hline Hurdle Rate & & $\begin{array}{l}0.0746 \\
(1.02)\end{array}$ & $\begin{array}{l}0.0747 \\
(0.94)\end{array}$ & $\begin{array}{l}0.0970 * * \\
(2.32)\end{array}$ \\
\hline $\mathrm{R}^{2}$ & & & & $\begin{array}{l}-0.501 * * * \\
(-3.05)\end{array}$ \\
\hline$S D I$ & & & & $\begin{array}{l}0.123 \\
(0.42)\end{array}$ \\
\hline Constant & $\begin{array}{l}0.578 * * * \\
(3.62)\end{array}$ & $\begin{array}{l}0.175 \\
(0.88)\end{array}$ & $\begin{array}{l}0.614 * \\
(1.84)\end{array}$ & $\begin{array}{l}0.968^{*} \\
(1.82)\end{array}$ \\
\hline Observations & 38,153 & 30,240 & 27,129 & 23,504 \\
\hline Adjusted $R^{2}$ & 0.054 & 0.075 & 0.147 & 0.176 \\
\hline
\end{tabular}




\section{Table 3: $U P$ and Interim Trading}

This table reports the results of Fama and MacBeth (1973) regressions of UP in month $t+1$ on portfolio turnover and different portfolio characteristics in month $t$. Portfolio turnover in month $t$ is calculated as the total of a fund firm's stock purchases and sales in month $t$ divided by 2 , divided by its total equity portfolio market capitalization in month $t-1$. As control variables, we add a fund firm's number of different stock positions, the portfolio's Herfindahl index (as a measure of portfolio concentration), size, beta, illiquidity (measured by the Amihud (2002) ratio), and the book-to-market ratio in month $t$ to our model. All control variables are based on the fund firm's disclosed holdings. Our sample covers hedge fund firms from the Union Hedge Fund Database constructed from combining the Eurekahedge, HFR, Morningstar, and Lipper TASS databases who report 13F long equity holdings to the SEC. The sample period is from January 1994 to December 2012. We use the Newey-West (1987) adjustment with 36 lags to adjust the standard errors for potential serial correlation. $*^{* *}, * *$, and $*$ denote statistical significance at the $1 \%, 5 \%$, and $10 \%$ level, respectively.

\begin{tabular}{lll}
\hline & $(1)$ & $(2)$ \\
& UP & UP \\
& $t+1$ & $t+1$ \\
\hline Portfolio Turnover & $0.152^{* *}$ & $0.123^{*}$ \\
& $(1.97)$ & $(1.74)$ \\
Number of Stocks & & 0.0000711 \\
& & $(0.81)$ \\
Herfindahl Index & & -0.618 \\
& & $(-1.22)$ \\
Size & & -0.0188 \\
& & $(-0.52)$ \\
Beta & & 0.0903 \\
& & $(1.02)$ \\
Illiquidity & & 0.0177 \\
& & $(0.34)$ \\
Book-To-Market & & -1.899 \\
& & $(-1.24)$ \\
Constant & & $0.811^{* *}$ \\
& $0.220^{* * *}$ & $(2.37)$ \\
\hline Observations & $(3.54)$ & 39,340 \\
Adjusted $R^{2}$ & 41,418 & 0.084 \\
\hline
\end{tabular}




\section{Table 4: UP and Derivatives Usage}

Panel A of this table reports the results of Fama and MacBeth (1973) regressions of UP of hedge fund firm $i$ in month $t+1$ on a hedge fund firm's sensitivity to the Agarwal and Naik (2004) out-of-the money (OTM) and at-the-money (ATM) call- and put option factors. We estimate a fund firm's sensitivity to the respective factor based on a rolling window of 36 monthly returns. Our sample covers hedge fund firms from the Union Hedge Fund Database constructed from combining the Eurekahedge, HFR, Morningstar, and Lipper TASS databases who report 13F long equity holdings to the SEC. The sample period is from January 1994 to December 2012. We use the Newey-West (1987) adjustment with 36 lags to adjust the standard errors for potential serial correlation and the Shanken (1992) correction to control for the errors-in-variables problem. Panel B of this table reports the results of Fama and MacBeth (1973) regressions of $U P$ of hedge fund firm $i$ in month $t+1$ on hedge fund firm $i$ 's long positions in call and put options in month $t$. We compute a hedge fund firm $i$ 's number of different stocks on which call positions are held (Number of Different Call Positions), the number of different stocks on which put positions are held (Number of Different Put positions), the number of equity shares underlying the call positions (Number of Equity Shares Underlying the Call Positions, in millions), the number of equity shares underlying the put positions (Number of Equity Shares Underlying the Put Positions, in millions), the value of equity shares underlying the call positions (Value of Equity Shares Underlying the Call Positions, in millions of dollars), and the value of equity shares underlying the put positions (Value of Equity Shares Underlying the Put Positions, in millions of dollars). The sample period for derivative positions is from April 1999 to December 2012. We use the Newey-West (1987) adjustment with 24 lags to adjust the standard errors for potential serial correlation. $* * * * *$, and $*$ denote statistical significance at the $1 \%, 5 \%$, and $10 \%$ level, respectively.

\section{Panel A: Option Sensitivities}

\begin{tabular}{lllll}
\hline Option Sensitivity & $(1)$ & $(2)$ & $(3)$ & $(4)$ \\
& UP & UP & UP & UP \\
\hline$\beta_{\text {OTMCall }}$ & -3.154 & & -3.579 & \\
$\beta_{\text {OTMPut }}$ & $(-1.01)$ & & $(-1.12)$ & \\
$\beta_{\text {ATMCall }}$ & & $3.859^{* * *}$ & $3.097^{* * *}$ & \\
$\beta_{\text {ATMPut }}$ & & $(2.15)$ & $(2.04)$ & -2.575 \\
Constant & & & & $(-1.23)$ \\
& & & & $3.302^{*}$ \\
Observations & & & & $(1.89)$ \\
Adjusted R & & & & $0.366^{* * *}$ \\
& $0.356^{* * * *}$ & $0.354^{* * *}$ & $0.357^{* * *}$ & $(4.66)$ \\
\hline & $(4.77)$ & $(4.70)$ & $(4.80)$ \\
\hline & 37,226 & 37,226 & 37,226 & 37,226 \\
& 0.017 & 0.017 & 0.033 & 0.034 \\
\hline
\end{tabular}


Panel B: Actual Filed Option Positions

\begin{tabular}{|c|c|c|c|c|}
\hline Derivatives holdings-based & (1) & (2) & (3) & (4) \\
\hline Variables & UP & UP & UP & UP \\
\hline Number of Different Call Positions & $\begin{array}{l}0.00497 \\
(1.28)\end{array}$ & & & $\begin{array}{l}0.00266 \\
(1.55)\end{array}$ \\
\hline Number of Different Put Positions & $\begin{array}{l}0.00227 * * \\
(2.48)\end{array}$ & & & $\begin{array}{l}0.00386^{* *} \\
(2.05)\end{array}$ \\
\hline $\begin{array}{l}\log (1+\text { Number of Equity Shares } \\
\text { Underlying the Call Positions) }\end{array}$ & & $\begin{array}{l}0.0360 \\
(0.36)\end{array}$ & & $\begin{array}{l}0.236 \\
(1.32)\end{array}$ \\
\hline $\begin{array}{l}\log (1+\text { Number of Equity Shares } \\
\text { Underlying the Put Positions })\end{array}$ & & $\begin{array}{l}0.0494 * * \\
(2.04)\end{array}$ & & $\begin{array}{l}0.0385 \\
(1.18)\end{array}$ \\
\hline $\begin{array}{l}\log (1+\text { Value of Equity Shares } \\
\text { Underlying the Call Positions) }\end{array}$ & & & $\begin{array}{l}-0.0285 \\
(-0.99)\end{array}$ & $\begin{array}{l}-0.0190 \\
(-1.53)\end{array}$ \\
\hline $\begin{array}{l}\log (1+\text { Value of Equity Shares } \\
\text { Underlying the Put Positions })\end{array}$ & & & $\begin{array}{l}0.0616^{*} \\
(1.86)\end{array}$ & $\begin{array}{l}0.0699 * * \\
(2.44)\end{array}$ \\
\hline Constant & $\begin{array}{l}0.223 * * * \\
(3.96)\end{array}$ & $\begin{array}{l}0.236 * * * \\
(4.07)\end{array}$ & $\begin{array}{l}0.247 * * * \\
(4.25)\end{array}$ & $\begin{array}{l}0.248 * * * \\
(4.27)\end{array}$ \\
\hline $\begin{array}{l}\text { Observations } \\
\text { Adjusted } R^{2}\end{array}$ & $\begin{array}{l}40,650 \\
0.007\end{array}$ & $\begin{array}{l}40,650 \\
0.010\end{array}$ & $\begin{array}{l}40,650 \\
0.010\end{array}$ & $\begin{array}{l}40,650 \\
0.026\end{array}$ \\
\hline
\end{tabular}




\section{Table 5: UP and Short-Selling Activities}

This table reports the results of Fama and MacBeth (1973) regressions of UP of hedge fund firm $i$ in month $t+l$ on a hedge fund firm's sensitivity to the Rapach, Ringgenberg, and Zhou (2016) aggregate short index in month $t$. We estimate a fund firm's sensitivity to the respective factor based on a rolling window of 36 monthly returns. As control variables we add a fund firm's number of different stock positions, the portfolio's Herfindahl index (as a measure of portfolio concentration), size, beta, illiquidity (measured by the Amihud (2002) ratio), and the book-to-market ratio in month $t$ to our model. All control variables are based on the fund firm's disclosed holdings. Our sample covers hedge fund firms from the Union Hedge Fund Database constructed from combining the Eurekahedge, HFR, Morningstar, and Lipper TASS databases who report 13F long equity holdings to the SEC. The sample period is from January 1994 to December 2012. We use the Newey-West (1987) adjustment with 36 lags to adjust the standard errors for potential serial correlation. ***, **, and * denote statistical significance at the $1 \%, 5 \%$, and $10 \%$ level, respectively.

\begin{tabular}{lll}
\hline & $(1)$ & $(2)$ \\
& UP & UP \\
& $t+1$ & $t+1$ \\
\hline$\beta_{\text {Shortlnterst }}$ & $0.308^{* * *}$ & $0.296^{* * *}$ \\
Number of Stocks & $(2.32)$ & $(2.06)$ \\
& & $0.000141^{*}$ \\
Herfindahl Index & & $(1.95)$ \\
& & 0.229 \\
Size & & $(0.39)$ \\
& & -0.0155 \\
Beta & & $(-1.31)$ \\
& & 0.102 \\
Illiquidity & & $(0.93)$ \\
& & 0.0330 \\
Book-To-Market & & $(0.11)$ \\
Constant & & -1.382 \\
& & $(-1.39)$ \\
Observations & $0.308^{* * *}$ & $0.537^{* * *}$ \\
Adjusted $R^{2}$ & $(5.42)$ & $(4.05)$ \\
\hline
\end{tabular}




\section{Table 6: UP and Confidential Holdings}

This table reports the results of Fama and MacBeth (1973) regressions of $U P$ of hedge fund firm $i$ in month $t+1$ on hedge fund firm $i$ 's confidential 13F positions in month $t$. Confidential holdings are quarter-end equity holdings that are disclosed with a delay through amendments to form $13 \mathrm{~F}$. We compute a hedge fund firm i's number of different confidential holding stocks (Number of Different Confidential Holdings), the number of equity shares underlying the confidential holdings (Number of Equity Shares Underlying the Confidential Holdings, in millions), and the value of equity shares underlying the confidential holdings positions (Value of Equity Shares Underlying the Confidential Holdings, in millions of dollars). Our sample covers hedge fund firms from the Union Hedge Fund Database constructed from combining the Eurekahedge, HFR, Morningstar, and Lipper TASS databases who report $13 \mathrm{~F}$ long equity holdings and confidential $13 \mathrm{~F}$ filing amendments to the SEC. The sample period for confidential holdings is from April 1999 to December 2012. We use the Newey-West (1987) adjustment with 24 lags to adjust the standard errors for potential serial correlation. ${ }^{* *}, * *$, and $*$ denote statistical significance at the $1 \%, 5 \%$, and $10 \%$ level, respectively.

\begin{tabular}{lllll}
\hline Confidential holdings variable & $(1)$ & $(2)$ & $(3)$ & $(4)$ \\
& UP & UP & UP & UP \\
\hline $\begin{array}{l}\text { Number of Different Confidential } \\
\text { Holdings }\end{array}$ & $\begin{array}{l}0.0235^{* *} \\
(2.52)\end{array}$ & & & 0.130 \\
& & & & $(1.53)$ \\
$\log (1+$ Number of Equity Shares & & $0.338^{*}$ & & $0.459^{* * *}$ \\
Underlying the Confidential Holdings) & & $(1.80)$ & & $(2.20)$ \\
& & & $0.234^{* *}$ & $0.140^{* *}$ \\
$\begin{array}{l}\log (1+\text { Value of Equity Shares Underlying } \\
\text { the Confidential Holdings) }\end{array}$ & & & $(2.13)$ & $(2.35)$ \\
Constant & $0.226^{* * *}$ & $0.226^{* * *}$ & $0.225^{* * *}$ & $0.224^{* * *}$ \\
& $(7.05)$ & $(7.06)$ & $(7.00)$ & $(6.99)$ \\
\hline $\begin{array}{l}\text { Observations } \\
\text { Adjusted } \mathrm{R}^{2}\end{array}$ & 40,317 & 40,317 & 40,317 & 40,317 \\
\hline
\end{tabular}




\section{Table 7: $U P$ and Future Returns: Univariate Portfolio Sorts}

This table reports the results from univariate portfolio sorts. Panel A reports the results from equally-weighted univariate portfolio sorts based on Fund Performance, Equity PF Performance, UP and the difference between $U P$ and Fund Performance in month $t$ and monthly excess returns in month $t+3$. In each month $t$, we sort all hedge funds into quintile portfolios based on the respective measure in increasing order. We then compute equally-weighted monthly average excess returns of these portfolios in month $t+3$. The column " $5-1$ " reports the difference in monthly average excess returns with corresponding statistical significance. In Panel B we repeat the univariate portfolio sorts in month $t$, but evaluate alphas in month $t+3$. We employ the Fung and Hsieh (2004) seven-factor model augmented with the book-to-market (HML) and momentum (UMD) factors. The column "5-1" reports the difference in monthly average alphas with corresponding statistical significance. Our sample is the intersection of hedge fund firms from the Union Hedge Fund Database (constructed from combining the Eurekahedge, HFR, Morningstar, and Lipper TASS databases) and firms that report 13F long equity holdings to the SEC. The sample period is from January 1994 to December 2012. We use the NeweyWest (1987) adjustment with 36 lags to adjust the standard errors for potential serial correlation. ***, **, and * denote statistical significance at the $1 \%, 5 \%$, and $10 \%$ level, respectively.

\section{Panel A: Excess Returns}

\begin{tabular}{lllll}
\hline Portfolio & $\begin{array}{l}(1) \\
\text { Fund Performance }\end{array}$ & $\begin{array}{l}(2) \\
\text { Equity PF } \\
\text { Performance }\end{array}$ & $\begin{array}{l}(3) \\
\text { UP }\end{array}$ & $\begin{array}{l}\text { UP - Fund } \\
\text { Performance }\end{array}$ \\
\hline 1 (Lowest) & $0.46 \%$ & $0.64 \%$ & $0.34 \%$ & $-0.12 \%$ \\
2 & $0.42 \%$ & $0.51 \%$ & $0.44 \%$ & $+0.02 \%$ \\
3 & $0.45 \%$ & $0.54 \%$ & $0.49 \%$ & $+0.04 \%$ \\
4 & $0.62 \%$ & $0.57 \%$ & $0.61 \%$ & $-0.01 \%$ \\
5 (Highest) & $0.80 \%$ & $0.51 \%$ & $0.87 \%$ & $+0.07 \%$ \\
\hline $5-1$ & $0.34 \%^{* * *}$ & $-0.13 \%$ & $0.53 \%$ *** & $+0.19 \% \%^{* * *}$ \\
\hline
\end{tabular}

\section{Panel B: Alphas from the nine-factor model}

\begin{tabular}{|c|c|c|c|c|}
\hline & (1) & (2) & (3) & (4) \\
\hline Portfolio & Fund Performance & $\begin{array}{l}\text { Equity PF } \\
\text { Performance }\end{array}$ & UP & $\begin{array}{l}\text { UP - Fund } \\
\text { Performance }\end{array}$ \\
\hline 1 (Lowest) & $\begin{array}{l}0.21 \\
(1.47)\end{array}$ & $\begin{array}{l}0.42 \% * * * \\
(3.35)\end{array}$ & $\begin{array}{l}0.09 \% \\
(0.82)\end{array}$ & $\begin{array}{l}-0.12 \% * \\
(-1.97)\end{array}$ \\
\hline 2 & $\begin{array}{l}0.19^{*} \\
(1.85)\end{array}$ & $\begin{array}{l}0.29 \% * * \\
(2.31)\end{array}$ & $\begin{array}{l}0.20 \% * \\
(1.85)\end{array}$ & $\begin{array}{l}+0.01 \% \\
(0.25)\end{array}$ \\
\hline 3 & $\begin{array}{l}0.22^{* *} \\
(2.19)\end{array}$ & $\begin{array}{l}0.31 \% * * * \\
(2.68)\end{array}$ & $\begin{array}{l}0.26 \% * * \\
(2.46)\end{array}$ & $\begin{array}{l}+0.04 \% \\
(0.66)\end{array}$ \\
\hline 4 & $\begin{array}{l}0.38 * * * \\
(3.27)\end{array}$ & $\begin{array}{l}0.29 * * \\
(2.06)\end{array}$ & $\begin{array}{l}0.35 \% * * * \\
(3.85)\end{array}$ & $\begin{array}{l}-0.03 \% \\
(-0.54)\end{array}$ \\
\hline 5 (Highest) & $\begin{array}{l}0.54 * * * \\
(4.55) \\
\end{array}$ & $\begin{array}{l}0.25 \% * \\
(1.85)\end{array}$ & $\begin{array}{l}0.64 \% * * * \\
(5.35)\end{array}$ & $\begin{array}{l}+0.10 \% \\
(+1.74) \\
\end{array}$ \\
\hline $5-1$ & $\begin{array}{l}0.33 \% * * * \\
(2.93)\end{array}$ & $\begin{array}{l}-0.17 \% \\
(-1.50) \\
\end{array}$ & $\begin{array}{l}0.55 \% \text { *** } \\
(4.14)\end{array}$ & $\begin{array}{l}+0.22 \% * * \\
(+2.32)\end{array}$ \\
\hline
\end{tabular}




\section{Table 8: UP and Future Returns: Univariate Portfolio Sorts with Additional Factors}

In this table, we regress the return of a portfolio consisting of funds in portfolio 1 with the lowest $U P$ subtracted from the returns of the funds in portfolio 5 with the highest $U P$, on different risk factors and asset classes. As risk factors, we use in addition to the factors of the augmented Fung and Hsieh (2004) nine-factor model presented in the first column, the Pástor and Stambaugh (2003) traded liquidity factor (PS Liqui), the Frazzini and Pedersen (2014) betting-against-beta factor (BAB), the Bali, Brown, and Caglayan (2014) macroeconomic uncertainty factor (Return Macro), the Buraschi, Kosowski, and Trojani (2014) correlation risk factor (Return CORR) the VIX (Return VIX), the Gao, Gao, and Song (2018) RIX factor (Return RIX), and the Agarwal, Ruenzi, and Weigert (2017) tail risk factor. As returns of different asset classes, we use the MSCI Emerging Market index (Return EM Equity), the Barclays US Aggregate Bond index (Return Bond), and the S\&P GSCI Commodity index (Return Commodity). Our sample is the intersection of hedge fund firms from the Union Hedge Fund Database (constructed from combining the Eurekahedge, HFR, Morningstar, and Lipper TASS databases) and firms that report $13 \mathrm{~F}$ long equity holdings to the SEC. The sample period is from January 1994 to December 2012. The sample period is from January 1994 to December 2012. We use the Newey-West (1987) adjustment with 36 lags to adjust the standard errors for potential serial correlation. ${ }^{* *}, * *$, and $*$ denote statistical significance at the $1 \%, 5 \%$, and $10 \%$ level, respectively.

\section{Panel A: Additional Risk Factors}

\begin{tabular}{|c|c|c|c|c|c|c|c|c|}
\hline & $\begin{array}{l}\text { (1) } \\
5-1 \mathrm{UP}\end{array}$ & $\begin{array}{l}(2) \\
5-1 \mathrm{UP}\end{array}$ & $\begin{array}{l}\text { (3) } \\
5-1 \mathrm{UP}\end{array}$ & $\begin{array}{l}(4) \\
5-1 \mathrm{UP}\end{array}$ & $\begin{array}{l}\text { (5) } \\
5-1 \mathrm{UP}\end{array}$ & $\begin{array}{l}\text { (6) } \\
5-1 \mathrm{UP}\end{array}$ & $\begin{array}{l}(7) \\
5-1 \mathrm{UP}\end{array}$ & $\begin{array}{l}(8) \\
5-1 \mathrm{UP}\end{array}$ \\
\hline S\&P & $\begin{array}{l}-0.0709 * * * \\
(-3.28)\end{array}$ & $\begin{array}{l}-0.0701 * * * \\
(-3.24)\end{array}$ & $\begin{array}{l}-0.0828 * * * \\
(-3.69)\end{array}$ & $\begin{array}{l}-0.0710^{\text {**** }} \\
(-3.28)\end{array}$ & $\begin{array}{l}-0.124 * * * \\
(-3.09)\end{array}$ & $\begin{array}{l}-0.0545 \\
(-1.24)\end{array}$ & $\begin{array}{l}-0.0697 * * * \\
(-3.24)\end{array}$ & $\begin{array}{l}-0.0875 \text { ** } \\
(-2.43)\end{array}$ \\
\hline SCMLC & $\begin{array}{l}0.00499 \\
(0.19)\end{array}$ & $\begin{array}{l}0.00489 \\
(0.19)\end{array}$ & $\begin{array}{l}-0.00602 \\
(-0.23)\end{array}$ & $\begin{array}{l}0.00499 \\
(0.19)\end{array}$ & $\begin{array}{l}-0.0131 \\
(-0.47)\end{array}$ & $\begin{array}{l}0.0137 \\
(0.42)\end{array}$ & $\begin{array}{l}0.00253 \\
(0.10)\end{array}$ & $\begin{array}{l}-0.000436 \\
(-0.02)\end{array}$ \\
\hline BD10RET & $\begin{array}{l}-0.00542 \\
(-0.11)\end{array}$ & $\begin{array}{l}-0.00714 \\
(-0.15)\end{array}$ & $\begin{array}{l}-0.00427 \\
(-0.09)\end{array}$ & $\begin{array}{l}-0.00269 \\
(-0.05)\end{array}$ & $\begin{array}{l}0.00339 \\
(0.07)\end{array}$ & $\begin{array}{l}-0.00806 \\
(-0.16)\end{array}$ & $\begin{array}{l}0.00398 \\
(0.08)\end{array}$ & $\begin{array}{l}-0.00339 \\
(-0.07)\end{array}$ \\
\hline BAAMTSY & $\begin{array}{l}-0.0467 \\
(-0.97)\end{array}$ & $\begin{array}{l}-0.0356 \\
(-0.72)\end{array}$ & $\begin{array}{l}-0.0150 \\
(-0.29)\end{array}$ & $\begin{array}{l}-0.0441 \\
(-0.90)\end{array}$ & $\begin{array}{l}-0.0727 \\
(-1.43)\end{array}$ & $\begin{array}{l}-0.0397 \\
(-0.78)\end{array}$ & $\begin{array}{l}-0.0321 \\
(-0.65)\end{array}$ & $\begin{array}{l}-0.0549 \\
(-1.09)\end{array}$ \\
\hline PTFSBD & $\begin{array}{l}0.000372 \\
(0.06)\end{array}$ & $\begin{array}{l}0.000337 \\
(0.05)\end{array}$ & $\begin{array}{l}-0.00143 \\
(-0.23)\end{array}$ & $\begin{array}{l}0.000731 \\
(0.11)\end{array}$ & $\begin{array}{l}-0.000106 \\
(-0.02)\end{array}$ & $\begin{array}{l}0.000192 \\
(0.03)\end{array}$ & $\begin{array}{l}-0.00148 \\
(-0.23)\end{array}$ & $\begin{array}{l}-0.000211 \\
(-0.03)\end{array}$ \\
\hline PTFSFX & $\begin{array}{l}0.00437 \\
(0.79)\end{array}$ & $\begin{array}{l}0.00408 \\
(0.74)\end{array}$ & $\begin{array}{l}0.00495 \\
(0.90)\end{array}$ & $\begin{array}{l}0.00410 \\
(0.73)\end{array}$ & $\begin{array}{l}0.00359 \\
(0.65)\end{array}$ & $\begin{array}{l}0.00467 \\
(0.84)\end{array}$ & $\begin{array}{l}0.00432 \\
(0.79)\end{array}$ & $\begin{array}{l}0.00422 \\
(0.76)\end{array}$ \\
\hline PTFSCOM & $\begin{array}{l}0.00719 \\
(1.03)\end{array}$ & $\begin{array}{l}0.00682 \\
(0.97)\end{array}$ & $\begin{array}{l}0.00636 \\
(0.91)\end{array}$ & $\begin{array}{l}0.00744 \\
(1.05)\end{array}$ & $\begin{array}{l}0.00732 \\
(1.05)\end{array}$ & $\begin{array}{l}0.00692 \\
(0.98)\end{array}$ & $\begin{array}{l}0.00731 \\
(1.05)\end{array}$ & $\begin{array}{l}0.00749 \\
(1.07)\end{array}$ \\
\hline HML & $\begin{array}{l}0.0590 * * \\
(2.27)\end{array}$ & $\begin{array}{l}0.0560 * * \\
(2.15)\end{array}$ & $\begin{array}{l}0.0888 * * * \\
(2.90)\end{array}$ & $\begin{array}{l}0.0578 * * \\
(2.19)\end{array}$ & $\begin{array}{l}0.0713 * * * \\
(2.64)\end{array}$ & $\begin{array}{l}0.0515 \\
(1.64)\end{array}$ & $\begin{array}{l}0.0762 * * * \\
(2.69)\end{array}$ & $\begin{array}{l}0.0664 * * \\
(2.29)\end{array}$ \\
\hline UMD & $\begin{array}{l}0.00728 \\
(0.44)\end{array}$ & $\begin{array}{l}0.00866 \\
(0.52)\end{array}$ & $\begin{array}{l}0.0182 \\
(1.04)\end{array}$ & $\begin{array}{l}0.00616 \\
(0.36)\end{array}$ & $\begin{array}{l}0.0117 \\
(0.70)\end{array}$ & $\begin{array}{l}0.00552 \\
(0.32)\end{array}$ & $\begin{array}{l}0.00476 \\
(0.29)\end{array}$ & $\begin{array}{l}0.0108 \\
(0.61)\end{array}$ \\
\hline PS Liqui & & $\begin{array}{l}-0.0246 \\
(-1.12)\end{array}$ & & & & & & \\
\hline $\mathrm{BAB}$ & & & $\begin{array}{l}-0.0490 * \\
(-1.80)\end{array}$ & & & & & \\
\hline Return Macro & & & & $\begin{array}{l}0.00702 \\
(0.31)\end{array}$ & & & & \\
\hline Return CORR & & & & & $\begin{array}{l}0.0631 \\
(1.56)\end{array}$ & & & \\
\hline Return VIX & & & & & & $\begin{array}{l}-0.0177 \\
(-0.43)\end{array}$ & & \\
\hline Return RIX & & & & & & & $\begin{array}{l}0.0354 \\
(1.48)\end{array}$ & \\
\hline Return Tailrisk & & & & & & & & $\begin{array}{l}0.0247 \\
(0.58)\end{array}$ \\
\hline Constant & $\begin{array}{l}0.554 * * * \\
(4.14)\end{array}$ & $\begin{array}{l}0.574 * * * \\
(4.24)\end{array}$ & $\begin{array}{l}0.561 * * * \\
(4.22)\end{array}$ & $\begin{array}{l}0.549 * * * \\
(3.90)\end{array}$ & $\begin{array}{l}0.543 * * * \\
(4.00)\end{array}$ & $\begin{array}{l}0.557 * * * \\
(4.13)\end{array}$ & $\begin{array}{l}0.522 * * * \\
(3.60)\end{array}$ & $\begin{array}{l}0.544 * * * \\
(5.84)\end{array}$ \\
\hline Observations & 190 & 190 & 190 & 190 & 190 & 190 & 190 & 190 \\
\hline Adjusted $R^{2}$ & 0.166 & 0.172 & 0.181 & 0.167 & 0.177 & 0.167 & 0.176 & 0.168 \\
\hline
\end{tabular}


Panel B: Other Asset Classes

\begin{tabular}{lllll}
\hline & $(1)$ & $(2)$ & $(3)$ & $(4)$ \\
& $5-1 \mathrm{UP}$ & $5-1 \mathrm{UP}$ & $5-1 \mathrm{UP}$ & $5-1 \mathrm{UP}$ \\
\hline S\&P & $-0.0709^{* * *}$ & $-0.0559^{*}$ & $-0.0662^{* * *}$ & $-0.0702^{* * *}$ \\
& $(-3.28)$ & $(-1.86)$ & $(-2.91)$ & $(-3.11)$ \\
SCMLC & 0.00499 & 0.0107 & 0.00536 & 0.00543 \\
BD10RET & $(0.19)$ & $(0.40)$ & $(0.21)$ & $(0.21)$ \\
& -0.00542 & -0.00591 & 0.0110 & -0.00614 \\
BAAMTSY & $(-0.11)$ & $(-0.12)$ & $(0.20)$ & $(-0.12)$ \\
& -0.0467 & -0.0409 & -0.0429 & -0.0457 \\
PTFSBD & $(-0.97)$ & $(-0.83)$ & $(-0.88)$ & $(-0.93)$ \\
& 0.000372 & -0.0000740 & 0.000997 & 0.000393 \\
PTFSFX & $(0.06)$ & $(-0.01)$ & $(0.16)$ & $(0.06)$ \\
& 0.00437 & 0.00448 & 0.00459 & 0.00437 \\
PTFSCOM & $(0.79)$ & $(0.81)$ & $(0.83)$ & $(0.79)$ \\
& 0.00719 & 0.00712 & 0.00740 & 0.00728 \\
HML & $(1.03)$ & $(1.02)$ & $(1.06)$ & $(1.03)$ \\
UMD & $0.0590^{* *}$ & $0.0561 * *$ & $0.0612^{* *}$ & $0.0593 * *$ \\
& $(2.27)$ & $(2.13)$ & $(2.33)$ & $(2.27)$ \\
Return EM Equity & 0.00728 & 0.00601 & 0.00789 & 0.00749 \\
Return Bond & $(0.44)$ & $(0.36)$ & $(0.48)$ & $(0.45)$ \\
Return Commodity & & -0.0143 & & \\
Constant & & $(-0.71)$ & & \\
& & & -0.0545 & \\
Observations & & & $(-0.66)$ & -0.00154 \\
Adjusted $R^{2}$ & & & & $(-0.11)$ \\
& & & & $0.556^{* * *}$ \\
& $0.554 * * *$ & $0.558^{* * * *}$ & $0.561 * * *$ & $(4.12)$ \\
\hline
\end{tabular}




\section{Table 9: Bivariate Portfolio Sorts}

This table reports the results the results of dependent bivariate portfolio sorts based on UP and Fund Performance and based on UP and Equity Portfolio Performance. Panel A reports equally-weighted future average returns of 25 portfolios double-sorted on Fund Performance and UP. First, we form quintile portfolios based on Fund Performance in month $t$. Then, within each quintile, we sort hedge funds into quintile portfolios based on $U P$ in month $t$. The last column shows the average of the future return of the respective UP quintile portfolio across the Fund Performance quintiles in month $t+3$. Panel B reports equally-weighted future average returns of 25 portfolios double-sorted on Equity PF Performance and UP. First, we form quintile portfolios based on Equity PF Performance in month $t$. Then, within each quintile, we sort stocks into quintile portfolios based on $U P$ in month $t$. The last column shows the average of the future return of the respective UP quintile portfolio across the Equity PF Performance quintiles in month $t+3$. Our sample is the intersection of hedge fund firms from the Union Hedge Fund Database (constructed from combining the Eurekahedge, HFR, Morningstar, and Lipper TASS databases) and firms that report $13 \mathrm{~F}$ long equity holdings to the SEC. The sample period is from January 1994 to December 2012. The sample period is from January 1994 to December 2012. We use the Newey-West (1987) adjustment with 36 lags to adjust the standard errors for potential serial correlation. ***, $* *$, and $*$ denote statistical significance at the $1 \%, 5 \%$, and $10 \%$ level, respectively.

\section{Panel A: Fund Performance and UP}

\begin{tabular}{|c|c|c|c|c|c|c|}
\hline & $\begin{array}{l}\text { Fund } \\
\text { Performance } 1\end{array}$ & $\begin{array}{l}\text { Fund } \\
\text { Performance } 2\end{array}$ & $\begin{array}{l}\text { Fund } \\
\text { Performance } 3\end{array}$ & $\begin{array}{l}\text { Fund } \\
\text { Performance } 4\end{array}$ & $\begin{array}{l}\text { Fund } \\
\text { Performance } 5\end{array}$ & Average \\
\hline UP 1 & $0.40 \%$ & $0.31 \%$ & $0.29 \%$ & $0.48 \%$ & $0.63 \%$ & $0.42 \%$ \\
\hline UP 2 & $0.23 \%$ & $0.36 \%$ & $0.53 \%$ & $0.36 \%$ & $0.57 \%$ & $0.41 \%$ \\
\hline UP 3 & $0.41 \%$ & $0.51 \%$ & $0.25 \%$ & $0.67 \%$ & $0.69 \%$ & $0.51 \%$ \\
\hline UP 4 & $0.76 \%$ & $0.44 \%$ & $0.41 \%$ & $0.64 \%$ & $1.02 \%$ & $0.65 \%$ \\
\hline UP 5 & $0.48 \%$ & $0.51 \%$ & $0.77 \%$ & $0.93 \%$ & $1.17 \%$ & $0.77 \%$ \\
\hline UP 5 - UP 1 & $\begin{array}{l}0.08 \% \\
(0.35)\end{array}$ & $\begin{array}{l}0.20 \% \\
(1.55)\end{array}$ & $\begin{array}{l}0.48 \% * * * \\
(3.44)\end{array}$ & $\begin{array}{l}0.45 \% * * * \\
(2.93)\end{array}$ & $\begin{array}{l}0.54 \% * * * \\
(2.65)\end{array}$ & $\begin{array}{l}0.35 \% * * \\
(2.18)\end{array}$ \\
\hline FH-9-Factor & $\begin{array}{l}0.09 \% \\
(0.44)\end{array}$ & $\begin{array}{l}0.27 \% * * \\
(2.01)\end{array}$ & $\begin{array}{l}0.54 * * * \\
(3.78)\end{array}$ & $\begin{array}{l}0.50 \% * * * \\
(3.15)\end{array}$ & $\begin{array}{l}0.44 * * \\
(2.03)\end{array}$ & $\begin{array}{l}0.37 \% * * \\
(2.28)\end{array}$ \\
\hline
\end{tabular}

\section{Panel B: Equity PF Performance and UP}

\begin{tabular}{lllllll}
\hline & $\begin{array}{l}\text { Equity PF } \\
\text { Performance 1 }\end{array}$ & $\begin{array}{l}\text { Equity PF } \\
\text { Performance 2 }\end{array}$ & $\begin{array}{l}\text { Equity PF } \\
\text { Performance 3 }\end{array}$ & $\begin{array}{l}\text { Equity PF } \\
\text { Performance 4 }\end{array}$ & $\begin{array}{l}\text { Equity PF } \\
\text { Performance 5 }\end{array}$ & Average \\
\hline UP 1 & $0.65 \%$ & $0.40 \%$ & $0.47 \%$ & $0.15 \%$ & $0.33 \%$ & $0.40 \%$ \\
UP 2 & $0.48 \%$ & $0.28 \%$ & $0.36 \%$ & $0.35 \%$ & $0.17 \%$ & $0.33 \%$ \\
UP 3 & $0.51 \%$ & $0.17 \%$ & $0.45 \%$ & $0.46 \%$ & $0.52 \%$ & $0.42 \%$ \\
UP 4 & $0.69 \%$ & $0.72 \%$ & $0.62 \%$ & $0.73 \%$ & $0.64 \%$ & $0.68 \%$ \\
UP 5 & $0.83 \%$ & $0.93 \%$ & $0.80 \%$ & $1.20 \%$ & $0.88 \%$ & $0.93 \%$ \\
\hline UP 5 - UP 1 & $0.19 \%$ & $0.53 \% \%^{* *}$ & $0.33 \% *$ & $1.05 \% * * *$ & $0.54 \% \%^{* *}$ & $0.53 \% \%^{* *}$ \\
& $(0.76)$ & $(2.73)$ & $(1.65)$ & $(5.38)$ & $(2.59)$ & $(2.62)$ \\
FH-9-Factor & $0.24 \%$ & $0.57 \% \%^{* *}$ & $0.33 \% *$ & $1.04 \% * * *$ & $0.39 \%^{*}$ & $0.52^{* *}$ \\
& $(0.98)$ & $(2.73)$ & $(1.66)$ & $(5.26)$ & $(1.82)$ & $(2.49)$ \\
\hline
\end{tabular}




\section{Table 10: UP and Future Returns: Fama-Macbeth (1973) Regressions}

Panel A of this table reports the results of Fama and MacBeth (1973) regressions of excess returns and nine-factor alphas in month $t+3$ on $U P$ and different fund characteristics in month $t$. As fund characteristics, we include a fund firm's monthly return, size, age, standard deviation (estimated over the previous 24 months), the delta of the incentive fee contract, a fund firm's management and incentive fee (in \%), minimum investment amount (in \$100 thousands), the length of a fund firm's lockup and restriction period (in years), indicator variables that equal one if the fund is an offshore fund, employs leverage, has a high-water mark and a hurdle rate, the $\mathrm{R}^{2}$ measure of Titman and Tiu (2011), and the SDI measure of Sun, Wang, and Zheng (2012). In Panel B, we report the results of Fama and MacBeth (1973) regressions of alphas in month $t+3$ on $U P$ and different fund characteristics (as in column (6) of Panel A) in times of high/low economic activitiy (based on the Chicago Fed National Activity Index, CFNAI > 0 / CFNAI < 0), high (low) market volatility, and in subsamples in the period from 1996-2003 and 2004-2012. We compute market volatility as the standard deviation of the CRSP value-weighted market return over the past 24 months. We classify $t$ as a high (low) market volatility period if the standard deviation is above (below) the median standard deviation over the whole sample period from 1996-2012. Panel C of this table reports the results of Fama and MacBeth (1973) regressions of future alphas at different future months on UP and different fund characteristics in month $t$. As fund characteristics, we use the same set of variables as in column (6) of Panel A. As the dependent variable we use the $t+1, t+2, t+6$, and $t+12$ nine-factor alphas. Our sample is the intersection of hedge fund firms from the Union Hedge Fund Database (constructed from combining the Eurekahedge, HFR, Morningstar, and Lipper TASS databases) and firms that report $13 \mathrm{~F}$ long equity holdings to the SEC. The sample period is from January 1994 to December 2012. We use the Newey-West (1987) adjustment with 36 lags to adjust the standard errors for potential serial correlation. $* * * * *$, and $*$ denote statistical significance at the $1 \%, 5 \%$, and $10 \%$ level, respectively. 
Panel A: Fama-Macbeth (1973) Regressions

\begin{tabular}{|c|c|c|c|c|c|c|}
\hline & $\begin{array}{l}\text { (1) } \\
\text { Fund Return } \\
t+3\end{array}$ & $\begin{array}{l}\text { (2) } \\
\text { Fund Return } \\
t+3\end{array}$ & $\begin{array}{l}\text { (3) } \\
\text { Fund Return } \\
t+3\end{array}$ & $\begin{array}{l}\text { (4) } \\
\text { Fund Return } \\
t+3\end{array}$ & $\begin{array}{l}\text { (5) } \\
\text { Fund Return } \\
t+3\end{array}$ & $\begin{array}{l}6) \\
\text { Nine-Factor } \\
\text { Alpha } \\
t+3\end{array}$ \\
\hline$U P$ & $\begin{array}{l}0.0545 * * * \\
(5.17)\end{array}$ & $\begin{array}{l}0.0229 * * \\
(2.49)\end{array}$ & $\begin{array}{l}0.0572 * * * \\
(3.63)\end{array}$ & $\begin{array}{l}0.0243 * * \\
(2.36)\end{array}$ & $\begin{array}{l}0.0268 * * * \\
(2.63)\end{array}$ & $\begin{array}{l}0.0478 * * * \\
(4.24)\end{array}$ \\
\hline Fund Return & & $\begin{array}{l}0.0199 \\
(1.61)\end{array}$ & & $\begin{array}{l}0.0199 * \\
(1.80)\end{array}$ & $\begin{array}{l}0.0265^{*} \\
(1.77)\end{array}$ & $\begin{array}{l}0.0265^{* * * *} \\
(2.73)\end{array}$ \\
\hline Size & & $\begin{array}{l}-0.0677^{*} \\
(-1.69)\end{array}$ & & $\begin{array}{l}-0.0743^{*} \\
(-1.84)\end{array}$ & $\begin{array}{l}-0.0887^{*} \\
(-1.67)\end{array}$ & $\begin{array}{l}-0.0330 \\
(-1.26)\end{array}$ \\
\hline Age & & $\begin{array}{l}0.0000650 \\
(0.08)\end{array}$ & & $\begin{array}{l}0.000551 \\
(0.52)\end{array}$ & $\begin{array}{l}0.000223 \\
(0.29)\end{array}$ & $\begin{array}{l}-0.000969 * * \\
(-2.34)\end{array}$ \\
\hline Standard & & $0.0585^{* *}$ & & $0.0615^{*}$ & $0.0602 *$ & 0.00518 \\
\hline Deviation & & (1.98) & & (1.69) & (1.71) & $(0.27)$ \\
\hline Delta & & $\begin{array}{l}0.0117 * * \\
(2.30)\end{array}$ & & $\begin{array}{l}0.00410^{*} \\
(1.71)\end{array}$ & $\begin{array}{l}0.00636 * \\
(1.85)\end{array}$ & $\begin{array}{l}0.00268 \\
(1.49)\end{array}$ \\
\hline Management Fee & & & $\begin{array}{l}0.0739 \\
(1.18)\end{array}$ & $\begin{array}{l}0.141 \\
(1.57)\end{array}$ & $\begin{array}{l}0.195 * * \\
(2.17)\end{array}$ & $\begin{array}{l}0.183 * * * \\
(4.58)\end{array}$ \\
\hline Incentive Fee & & & $\begin{array}{l}-0.00495 \\
(-0.45)\end{array}$ & $\begin{array}{l}-0.00665 \\
(-0.53)\end{array}$ & $\begin{array}{l}-0.00760 \\
(-0.57)\end{array}$ & $\begin{array}{l}-0.0120 \\
(-1.54)\end{array}$ \\
\hline $\begin{array}{l}\text { Minimum } \\
\text { Investment }\end{array}$ & & & $\begin{array}{l}0.000455 \\
(0.33)\end{array}$ & $\begin{array}{l}0.00214 * * \\
(2.37)\end{array}$ & $\begin{array}{l}0.00180 * \\
(1.72)\end{array}$ & $\begin{array}{l}0.000230 \\
(0.40)\end{array}$ \\
\hline Lockup Period & & & $\begin{array}{l}0.167 * * \\
(2.04)\end{array}$ & $\begin{array}{l}0.175^{*} \\
(1.89)\end{array}$ & $\begin{array}{l}0.133 \\
(1.30)\end{array}$ & $\begin{array}{l}0.140^{*} \\
(1.72)\end{array}$ \\
\hline $\begin{array}{l}\text { Restriction } \\
\text { Period }\end{array}$ & & & $\begin{array}{l}0.0640 \\
(0.47)\end{array}$ & $\begin{array}{l}0.233^{*} \\
(1.89)\end{array}$ & $\begin{array}{l}0.236^{*} \\
(1.85)\end{array}$ & $\begin{array}{l}0.177 * * * \\
(3.07)\end{array}$ \\
\hline Offshore & & & $\begin{array}{l}0.142^{*} \\
(1.74)\end{array}$ & $\begin{array}{l}0.153 * * \\
(2.06)\end{array}$ & $\begin{array}{l}0.127 * \\
(1.72)\end{array}$ & $\begin{array}{l}0.193 * * \\
(2.51)\end{array}$ \\
\hline Leverage & & & $\begin{array}{l}0.111^{*} \\
(1.73)\end{array}$ & $\begin{array}{l}0.0377 \\
(0.66)\end{array}$ & $\begin{array}{l}0.0138 \\
(0.32)\end{array}$ & $\begin{array}{l}-0.0518 \\
(-1.39)\end{array}$ \\
\hline High Watermark & & & $\begin{array}{l}-0.0325 \\
(-0.34)\end{array}$ & $\begin{array}{l}-0.0490 \\
(-0.53)\end{array}$ & $\begin{array}{l}0.0196 \\
(0.19)\end{array}$ & $\begin{array}{l}0.0317 \\
(0.41)\end{array}$ \\
\hline Hurdle Rate & & & $\begin{array}{l}0.175^{* * * *} \\
(4.19)\end{array}$ & $\begin{array}{l}0.244 * * * \\
(4.78)\end{array}$ & $\begin{array}{l}0.223 * * * \\
(5.07)\end{array}$ & $\begin{array}{l}0.216^{* * * *} \\
(5.92)\end{array}$ \\
\hline $\mathrm{R}^{2}$ & & & & & $\begin{array}{l}-0.192 * \\
(-1.73)\end{array}$ & $\begin{array}{l}-0.0573 \\
(-1.49)\end{array}$ \\
\hline$S D I$ & & & & & $\begin{array}{l}0.336 \\
(1.52)\end{array}$ & $\begin{array}{l}0.0647 \\
(0.40)\end{array}$ \\
\hline Constant & $\begin{array}{l}0.533 * * * \\
(2.73)\end{array}$ & $\begin{array}{l}0.624 * * \\
(2.18) \\
\end{array}$ & $\begin{array}{l}0.281 \\
(1.07)\end{array}$ & $\begin{array}{l}0.255 \\
(0.79) \\
\end{array}$ & $\begin{array}{l}0.517 \\
(1.19)\end{array}$ & $\begin{array}{l}0.262 \\
(1.22)\end{array}$ \\
\hline Observations & 40,940 & 36,561 & 28,652 & 26,081 & 22,919 & 22,868 \\
\hline Adjusted $R^{2}$ & 0.012 & 0.213 & 0.095 & 0.289 & 0.326 & 0.246 \\
\hline
\end{tabular}

Panel B: Alphas associated with UP in Different States of the World

\begin{tabular}{lllllll}
\hline & $(1)$ & $(2)$ & $(3)$ & $(4)$ & $(5)$ & $(6)$ \\
& $C F N A I>0$ & CFNAI $<0$ & $\begin{array}{l}\text { High Market } \\
\text { Volatility }\end{array}$ & $\begin{array}{l}\text { Low Market } \\
\text { Volatility }\end{array}$ & $\begin{array}{l}\text { Subsample } \\
1994-2003\end{array}$ & $\begin{array}{l}\text { Subsample } \\
2004-2012\end{array}$ \\
\hline$U P$ & $0.0444^{*}$ & $0.0496^{* * *}$ & $0.0623^{* * *}$ & $0.0278^{*}$ & $0.0690^{* * *}$ & $0.0332^{* * * *}$ \\
& $(1.72)$ & $(3.79)$ & $(4.43)$ & $(1.93)$ & $(2.89)$ & $(3.13)$ \\
Control & Yes & Yes & Yes & Yes & Yes & Yes \\
$\begin{array}{l}\text { Variables } \\
\text { Observations }\end{array}$ & 9,090 & 13,778 & 11,968 & 10,900 & 6,903 & 15,965 \\
Adjusted $R^{2}$ & 0.226 & 0.222 & 0.232 & 0.213 & 0.250 & 0.198 \\
\hline
\end{tabular}


Panel C: Alphas at Different Horizons

\begin{tabular}{llllll}
\hline & $(1)$ & $(2)$ & $(3)$ & $(4)$ & $(5)$ \\
& Fund & Fund & Fund & Fund & Fund \\
& Alpha & Alpha & Alpha & Alpha & Alpha \\
& $t+3$ & $t+1$ & $t+2$ & $t+6$ & $t+12$ \\
\hline$U P$ & $0.0478^{* * *}$ & $0.0289^{* * *}$ & $0.0284^{* * *}$ & $0.0253^{* * *}$ & $0.0362^{* * *}$ \\
& $(4.24)$ & $(3.28)$ & $(3.28)$ & $(3.01)$ & $(3.51)$ \\
Controls & Yes & Yes & Yes & Yes & Yes \\
Observations & 22,868 & 23,503 & 23,188 & 22,265 & 20,774 \\
Adjusted $\mathrm{R}^{2}$ & 0.246 & 0.242 & 0.247 & 0.248 & 0.251 \\
\hline
\end{tabular}




\section{Table 11: UP and Hedge Fund Performance: Robustness Checks}

This table reports the results from robustness checks of the relation between $U P$ of hedge funds in month $t$ and their monthly performance in month $t+3$. We investigate the robustness if we apply a value-weighted sorting procedure instead of an equally-weighted sorting procedure, use only single hedge fund firms in the analysis, restrict our sample to hedge fund firms with an equity long-short strategy, assign a delisting return of $-1.61 \%$ to those hedge funds that leave the database, and use the Getmansky, Lo, and Makarov (2004) methodology to unsmooth hedge fund returns. Panel A displays the results of from the same univariate portfolio sorts as in Panel B of Table 2 (column 3), riskadjusted for the augmented Fung and Hsieh (2004) nine-factor model. Panel B reports the results of Fama and MacBeth (1973) regressions as in Panel A of Table 5 (column 6) of future alphas in month $t+3$ on $U P$ and different fund characteristics measured in month $t$. Our sample is the intersection of hedge fund firms from the Union Hedge Fund Database (constructed from combining the Eurekahedge, HFR, Morningstar, and Lipper TASS databases) and firms that report 13F long equity holdings to the SEC. The sample period is from January 1994 to December 2012. We use the NeweyWest (1987) adjustment with 36 lags to adjust the standard errors for potential serial correlation. ***, $* *$, and $*$ denote statistical significance at the $1 \%, 5 \%$, and $10 \%$ level, respectively. We only display the results of the relation between UP and future performance (control variables are included but suppressed in the table).

Panel A: Portfolio Sorts

\begin{tabular}{lllllll}
\hline & $(1)$ & $(2)$ & $(3)$ & $(4)$ & $(5)$ & $(6)$ \\
& Baseline & $\begin{array}{l}\text { Value- } \\
\text { Weighted }\end{array}$ & $\begin{array}{l}\text { Single Hedge } \\
\text { Funds }\end{array}$ & $\begin{array}{l}\text { Only Equity } \\
\text { Long-Short } \\
\text { Fund Firms }\end{array}$ & $\begin{array}{l}\text { Delisting } \\
\text { Return }\end{array}$ & $\begin{array}{l}\text { Return } \\
\text { Smoothing }\end{array}$ \\
\hline $5-1 U P$ & $0.55 \% * * *$ & $0.43 \% * *$ & $0.48 \% * * *$ & $0.54 \% * * *$ & $0.51 \% * * *$ & $0.41 \% * * *$ \\
& $(4.14)$ & $(2.43)$ & $(3.45)$ & $(3.81)$ & $(3.99)$ & $(3.12)$ \\
\hline
\end{tabular}

\section{Panel B: Fama-MacBeth Regressions}

\begin{tabular}{lllllll}
\hline & $(1)$ & $(2)$ & $(3)$ & $(4)$ & $(5)$ & $(6)$ \\
& Baseline & $\begin{array}{l}\text { Value- } \\
\text { Weighted }\end{array}$ & $\begin{array}{l}\text { Single Hedge } \\
\text { Funds }\end{array}$ & $\begin{array}{l}\text { Only Equity } \\
\text { Long-Short } \\
\text { Fund Firms }\end{array}$ & $\begin{array}{l}\text { Delisting } \\
\text { Return }\end{array}$ & $\begin{array}{l}\text { Return } \\
\text { Smoothing }\end{array}$ \\
\hline$U P$ & $0.0478 * * *$ & $0.0414 * * *$ & $0.0354 * * *$ & $0.0454 * *$ & $0.0469 * * *$ & $0.0341 * * *$ \\
& $(4.24)$ & $(4.14)$ & $(2.98)$ & $(3.56)$ & $(4.15)$ & $(3.77)$ \\
Controls & Yes & Yes & Yes & Yes & Yes & Yes \\
Observations & 22,868 & 22,868 & 6,175 & 13,526 & 22,868 & 22,868 \\
Adjusted R $\mathrm{R}^{2}$ & 0.246 & 0.246 & 0.295 & 0.301 & 0.245 & 0.221 \\
\hline
\end{tabular}

